\title{
Soil properties and pre-Columbian settlement patterns in the Monumental Mounds Region of the Llanos de Moxos, Bolivian Amazon
}

\author{
U. Lombardo ${ }^{1,2}$, S. Denier ${ }^{1}$, and H. Veit ${ }^{1}$ \\ ${ }^{1}$ Universität Bern, Geographisches Institut, Hallerstrasse 12, 3012 Bern, Switzerland \\ ${ }^{2} \mathrm{CaSeS}$ research group, IMF-CSIC, C/Egipciaques, 15-08001 Barcelona, Spain
}

Correspondence to: U. Lombardo (lombardo@ giub.unibe.ch)

Received: 5 May 2014 - Published in SOIL Discuss.: 15 May 2014

Revised: - - Accepted: 26 September 2014 - Published: 6 January 2015

\begin{abstract}
In the present paper we explore to what degree soil properties might have influenced pre-Columbian settlement patterns in the Monumental Mounds Region (MMR) of the Llanos de Moxos (LM), Bolivian Amazon. Monumental mounds are pre-Hispanic earth buildings and were preferentially built on mid- to late Holocene palaeolevees of the Grande River (here denominated PR1), while levees of older palaeorivers (PR0) were only sparsely occupied. We dug two transects across PR0 and PR1 levee-backswamp catenas and analysed them for grain size, $\mathrm{pH}$, cation exchange capacity (CEC) and $\mathrm{C}_{\text {org }}$. Our data show that PR1 soils, where the density of mounds is higher, have far greater agricultural potential than PR0 soils, which are affected by aluminium toxicity in the backswamps and by high levels of exchangeable sodium in the levees. This study provides new data on the soil properties of the south-eastern Bolivian Amazon and reinforces the hypothesis that environmental constraints and opportunities exerted an important role on pre-Columbian occupation patterns and the population density reached in the Bolivian Amazon.
\end{abstract}

\section{Introduction}

Soils are among the most important factors in determining agricultural productivity and shaping prehistoric settlement patterns (Simpson et al., 2002; Kirch et al., 2004). In Amazonia, the debate about the relationship between soils, population growth and settlement patterns has historically been dominated by Meggers' view that Amazonian poor soils hindered cultural development and allowed only the existence of small nomadic groups (Meggers, 1954, 1971). Meggers' position has been regarded as the "standard model" of Amazonian prehistory (Stahl, 2002). As the establishment of large and permanent settlements is the prerequisite for the development of complex societies (Johnson and Earle, 2000), according to the standard model, the formation of complex societies in Amazonia was impossible for ecological reasons. Nevertheless, Meggers' conclusions have been controversial and have received increasing criticisms on two main fronts. On the one hand, some researchers have noted that Meggers was incorrect in assuming that all Amazonia is characterized by having poor soils. Many scholars have pointed out that the floodplain soils along most Amazonian rivers, the varzea, are indeed richer than the interfluvial areas, terra firme, and able to sustain dense and sedentary populations (Lathrap, 1970; Carneiro, 1995; Denevan, 1996; Rebellato et al., 2009). On the other hand, the more recent discovery of large sedentary pre-Columbian settlements in areas far from the main waterways (Heckenberger et al., 1999, 2008; Heckenberger and Neves, 2009; Lombardo and Prümers, 2010) represents a challenge to the varzea/terra firme dichotomy. Environmental variability within Amazonia is greater than what archaeologists first thought (Moran, 1995); hence, patterns of preColumbian spatial occupation are likely to be influenced by a wider and more complex set of environmental variables than those first envisaged (Heckenberger et al., 1999). It has been proposed that, on the whole, preferential areas for large preColumbian settlements in Amazonia were located along the more fertile riverine environments (McMichael et al., 2014), 
in areas where seasonality is more pronounced, thus facilitating slash-and-burn agriculture (Bush and Silman, 2007), and in areas closer to the Andes, where recent alluvia provide relatively drained and fertile land (Lombardo et al., 2012). At the local level, however, past and present fluvial dynamics and/or small changes in the topography which affect drainage can significantly alter the local environment and increase the suitability of certain sites to host permanent settlements (see for example Lombardo et al., 2013a). Although these studies challenge Meggers' main conclusions, they share with Meggers the view that pre-existing environmental factors exerted an important control on pre-Columbian settlement patterns in Amazonia. However, this remains a controversial issue per se and is questioned by a second group of scholars, who argue that approaches that link the evolution of pre-Columbian cultures to pre-existing environmental constraints and opportunities underestimate people's ability to "domesticate" the environment (Balèe, 1989; Balée and Erickson, 2006; Erickson, 2008; Denevan, 2012). According to this view, preColumbians adapted their environment to themselves, rather than themselves to it (Erickson, 2006). This line of thought has encouraged recent studies that have put much emphasis on demonstrating how pre-Columbians' impact on the Amazon ecosystems was widespread, with long lasting legacies in terms of forest biodiversity and the creation of anthropogenic soils (Heckenberger et al., 2007; Clement and Junqueira, 2010; Levis et al., 2012; Junqueira and Clement, 2012). In fact, the current debate has moved on and is no longer centred on how the environment influenced pre-Columbian occupation in Amazonia, but rather on assessing the extent to which pre-Columbians modified the "pristine" Amazonia. In this regard, most environmental scientists hold the view that pre-Columbians settled on only a small fraction of the area of Amazonia and that their impact was localized, with few, if any, effects on most parts of Amazonia (Bush et al., 2007; Peres et al., 2010; Barlow et al., 2012a, b; McMichael et al., 2012, 2014). The bulk of data around which this debate is unfolding is a combination of charcoal records from lakes and soils (Arroyo-Kalin, 2012; McMichael et al., 2012; Urrego et al., 2013) and the analysis of modern Amazonian tree species composition, which seems to reflect past human practices (Clement, 1999; Clement and Junqueira, 2010; Peres et al., 2010; Barlow et al., 2012a; Levis et al., 2012). However, the difficulty of performing a statistically reliable sampling of an area as large and diverse as Amazonia is a significant obstacle (Bush and Silman, 2007). Alternatively, if links between pre-existing environmental conditions (mostly edaphology) and pre-Columbian settlement patterns could be established at the scale of the archaeological occupation, then the combination of soils, topography, climate and hydrology could serve to formulate testable hypotheses about where archaeological sites are likely to be found (McMichael et al., 2014). Moreover, the combination of archaeological surveys and the edaphological characterization of their surroundings could permit the estimation of the pre-Columbian population density in a given site and the percentage of occupied land in any edaphologically homogeneous territory, hence, providing an independent data set against which other proxies, such as charcoal, pollen or tree species compositions, could be tested.

The Llanos de Moxos (LM), a seasonally flooded savannah in the southern Amazonia, is an ideal site to study the relationship between pre-Columbian occupations and preexisting environmental settings. Inhabited since the early Holocene (Lombardo et al., 2013b), the LM is made up of a diverse set of geo-ecological subregions that host a rich array of pre-Columbian earthworks: canals, causeways, fish weirs, raised fields and monumental earth mounds (Denevan, 1966; Erickson, 2008; Walker, 2008; Lombardo et al., 2011b; Prümers, 2010). These earthworks are unevenly distributed in the LM (Fig. 1); some types of earthworks are present in some areas, whilst absent in others (Denevan, 1966; Lombardo et al., 2011b). The LM, therefore, offers an excellent opportunity to compare different kinds of cultural landscapes and assess their relationship to different pre-Columbian cultures and environmental settings. Lombardo et al. (2013a) have recently shown that differences in the level of social complexity achieved in two different regions of the LM, as inferred from the study of the different types of earthworks present, seem to respond to important differences in soil geochemistry and hydrology. These two areas are the Platform Fields Region (PFR), north of Santa Ana de Yacuma, where more than 50000 ha of raised fields are found (Lombardo, 2010), and the Monumental Mounds Region (MMR), east of Trinidad (Fig. 1), where hundreds of monumental earthen mounds were built (Lombardo and Prümers, 2010). Monumental mounds, locally known as lomas, are earth buildings that follow structural patterns and geometric rules. They are often built along palaeoriver channels. The average mound covers an area of $5.5 \mathrm{ha}$ and consists of a 3 to $5 \mathrm{~m}$ elevated earthen platform with one or more pyramidal structures. They can be up to $21 \mathrm{~m}$ high and as large as $20 \mathrm{ha}$. Monumental mounds probably had an important political and ritual role (Erickson, 2000; Prümers, 2009; Lombardo and Prümers, 2010); they are by far the most labour-intensive earthwork in the LM. However, these two regions also differ in the types of pre-Columbian pottery that has been unearthed (Walker, 2011a; Jaimes-Betancourt, 2012) and are more than $100 \mathrm{~km}$ apart; thus, cultural diversity could also explain the diversity in the type of earthworks found and the lack of raised fields in the MMR (Walker, 2011b). In order to disentangle the cultural from the environmental determinants, we here examine the soil properties of two locations within the same cultural region in the MMR, but where the density of settlements and earthworks is considerably different.

In the MMR, in the south-eastern LM, pre-Columbians settled along palaeolevees and built monumental mounds, causeways, canals and other earthworks which, together with the results of archaeological excavations (Prümers, 2008, 


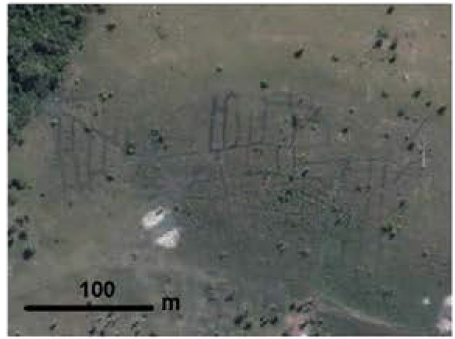

Ditched fields

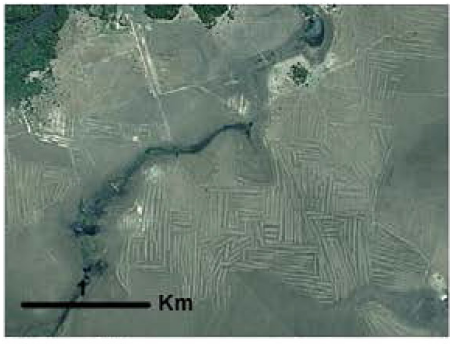

Platform fields
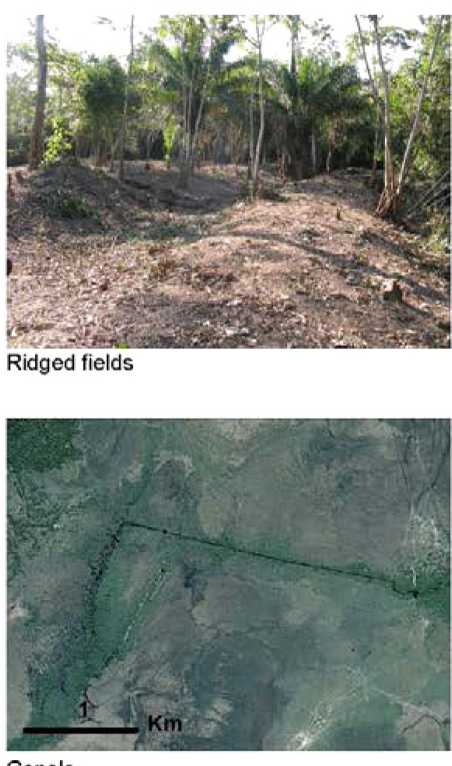

Canals

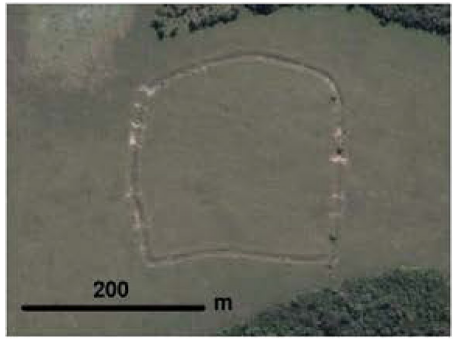

Ring ditches

(⿸丆口

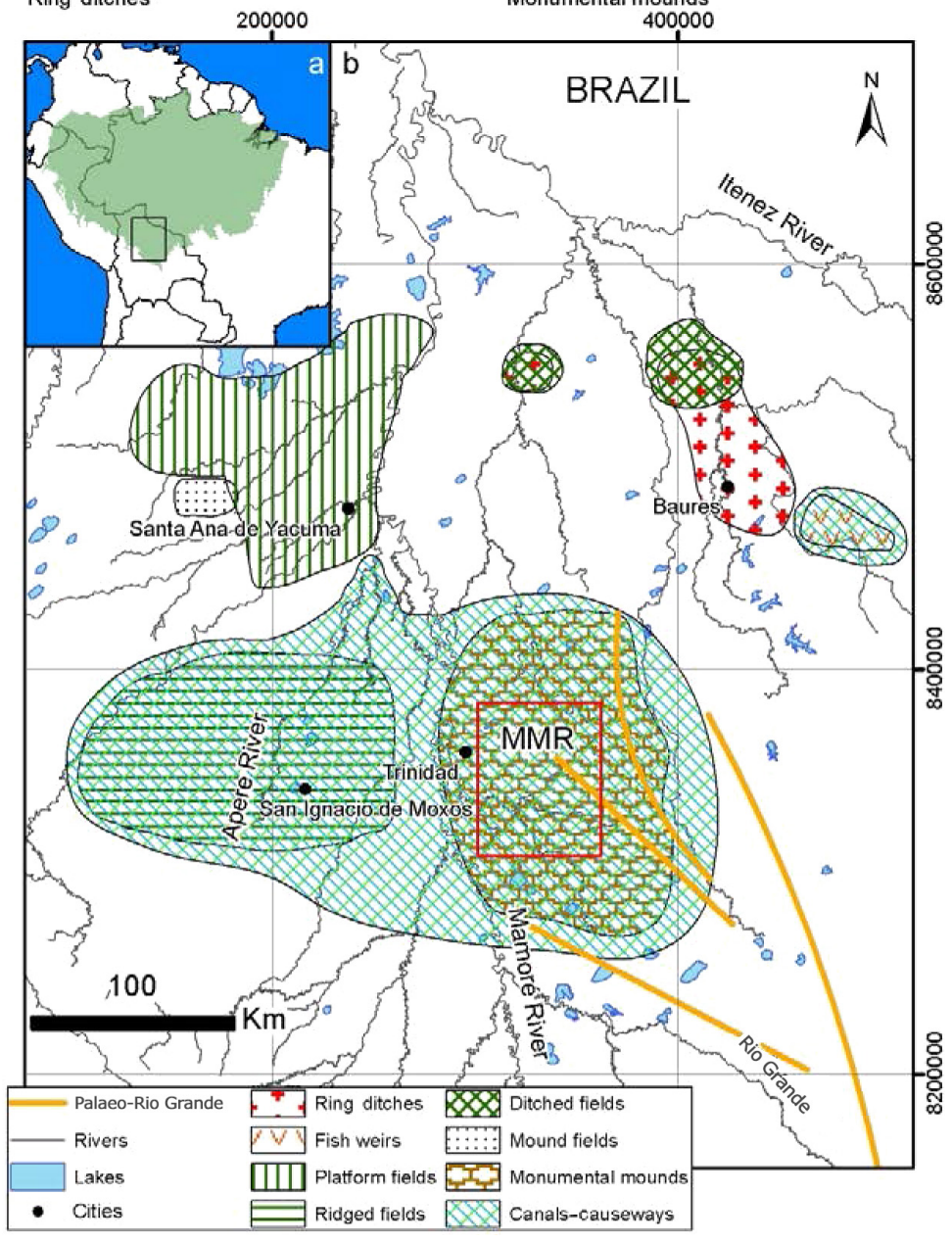

Figure 1. Different pre-Columbian earthworks that exist in the Llanos de Moxos and their spatial distribution (adapted from Lombardo et al., 2011b). Platform, ridged and ditched fields are different types of pre-Columbian agricultural raised fields. The red box defines the area in Fig. 2.

2009; Jaimes-Betancourt, 2012), attest that they formed here a complex society with a relatively high population density (Lombardo and Prümers, 2010). Archaeologists have shown that the former inhabitants of the MMR cultivated several crops including maize (Bruno, 2010; Dickau et al., 2012). However, unlike other regions in the LM where raised agricultural fields are widespread (Walker, 2004; Michel, 1999; Lombardo et al., 2011a, b), no evidence of pre-Columbian agricultural fields has been found in the MMR. Lombardo et al. (2012) formulated the hypothesis that pre-Columbians thrived in the MMR thanks to the fertile and relatively well drained sediments of a sedimentary lobe deposited by the Grande River during the mid- to late Holocene. However, the MMR does not overlap exactly with the sedimentary lobe, and there are monumental mounds that are built on palaeolevees of older, probably Late Pleistocene (Plotzki, 2013), rivers. It can be observed that mounds built on these older levees (PR0) are found in a considerably lower density than mounds built on the palaeolevees of the Grande River (PR1). The main aim of the present study is to test if the differ- 
ences in soil properties between the older palaeolevees and those deposited by the Grande River within the area of the sedimentary lobe can explain the differences observed in the density of mounds. In order to test this hypothesis, two transects have been dug across two levee-backswamp catenas: the first at the centre of the MMR, where the density of preColumbian earthworks is high, with almost one monumental mound every $3 \mathrm{~km}$, and a second one in the south of the MMR, where mound density sharply declines (Fig. 2).

\section{Study area: the Llanos de Moxos and the Monumental Mounds region}

The Llanos de Moxos (LM) is located in the northeast of Bolivia, between 12 and $16^{\circ} \mathrm{S}$. It is a seasonally flooded savannah crisscrossed by rivers and palaeorivers, covering an area of $150000 \mathrm{~km}^{2}$. This vast floodplain is drained by three major rivers: the Mamoré River, which runs through the central plains, the Beni River, which runs through the northwestern margin of the LM, and the Iténez (Guaporé) River, which runs through its northeastern margin. These three rivers converge with the Madre de Dios River forming the Madeira River, one of the biggest tributaries of the Amazon River.

According to the Köppen classification, the climate of the LM is Awin and becomes Amwi in the area close to the Andes (Hanagarth, 1993). Precipitation follows a north-south gradient, going from $1500 \mathrm{~mm}_{\text {year }}{ }^{-1}$ in the northern part to $2500 \mathrm{~mm} \mathrm{year}^{-1}$ in the southern part (Hijmanns et al., 2005). Rainfall is concentrated during the austral summer, from November to March. During the dry season occasional rainfall occurs, as the result of sharp drops in the temperature brought about by cold southern winds, locally known as surazos. The forest-savannah boundary in the LM is determined by the seasonal floods. Anoxic conditions caused by floods, combined with severe drought, impede tree growth (Mayle et al., 2007). The savannah occupies the low-lying regions of the LM, which are filled with fine quaternary sediments. The clay content of these sediments can be as high as $90 \%$ (Boixadera et al., 2003). In the south of the LM, elevated fluvial levees that stay above the floods permit the growth of patches of forest. In the north, soils are characterized by lateritic crusts which host Cerrado-like vegetation (Langstroth Plotkin, 2011; Navarro, 2011).

In the southeast of the LM there is an area of approximately $15000 \mathrm{~km}^{2}$ where hundreds of networked monumental earth mounds were built by pre-Columbians between AD 400 and 1400 (Jaimes-Betancourt, 2012; Lombardo and Prümers, 2010): the Monumental Mounds Region (MMR). Impressive anthropogenic earthworks are found in other parts of the LM (Fig. 1), but only in the MMR there is clear evidence of a complex pre-Columbian culture. Archaeologists have discovered elaborately decorated pottery and different burial traditions (Prümers, 2009, 2008; Jaimes-Betancourt, 2012), indicating specialized craftsmen and socialdistinction.
There is also evidence of political structure in the spatial distribution of the mounds and associated canals and causeways. It would seem that the monumental mounds were occupied continuously and simultaneously, given the existence of the same cultural phases found in different monumental mounds (Jaimes-Betancourt, 2012) and the presence of causeways and canals connecting the mounds among each other (Lombardo and Prümers, 2010). Archaeobotanical analysis of sediments from monumental mounds shows that maize ( $\mathrm{Zea}$ mays $\mathrm{L}$.) was an important part of the diet of pre-Columbians, together with manioc (Manihot esculenta Crantz) (Bruno, 2010; Dickau et al., 2012). Other cultigens found in archaeological excavations include chili pepper, squash, jack bean, sweet potato, peanuts, and cotton. It is surprising that raised fields, which are abundant in other parts of the LM (Fig. 1), are absent in the MMR. Pollen analysis from a lake situated within a savannah in the MMR (lake San José) shows the presence of maize pollen, suggesting that maize was cultivated in the savannah from AD 400 to AD 1280 (Whitney et al., 2013).

The landscape in the MMR is characterized by savannahs interwoven with forested levees of palaeorivers (Figs. 1 and 2). These forested areas account for approximately $25 \%$ of the MMR. The palaeorivers in the MMR belong to different generations of rivers which are here grouped into two categories: the generation PR0 and the generation PR1 (Fig. 2). PR0 comprises the older levees, which were deposited during the Late Pleistocene (Plotzki, 2013). These are partly covered by the levees of PR1, which were deposited by the Grande River during a mid- to late Holocene highly avulsive phase (Lombardo et al., 2012).

The Grande River also deposited finer sediments between the palaeochannels in the MMR; the combination of avulsions and backswamp sedimentation resulted in the deposition of a sedimentary lobe. This sedimentary lobe created a convex topography, improving the drainage of the whole area (Lombardo et al., 2012). The mid-Holocene avulsive phase of the Grande River created relief at a local scale - the palaeolevees - and a convex topography at a larger regional scale - the sedimentary lobe. In the area where the sedimentary lobe was deposited, the savannahs host Cyperus giganteus and Thalia geniculata, which are typical plants of nutrientrich wetlands (Langstroth Plotkin, 2011). We have argued that, thanks to the fertile sediments deposited by the Grande River and the relatively good drainage due to its convex topography, the MMR was able to sustain denser populations than anywhere else in the LM (Lombardo et al., 2011b, 2012, 2013a). Nevertheless, within the MMR, mounds are not randomly distributed but instead clustered around political units (Lombardo and Prümers, 2010). It can also be observed that the density of monumental mounds decreases towards the south, where the palaeolevees are PR0 (Fig. 2), and that all the clusters of mounds are within the Grande River sedimentary lobe, where the palaeolevees are PR1. 


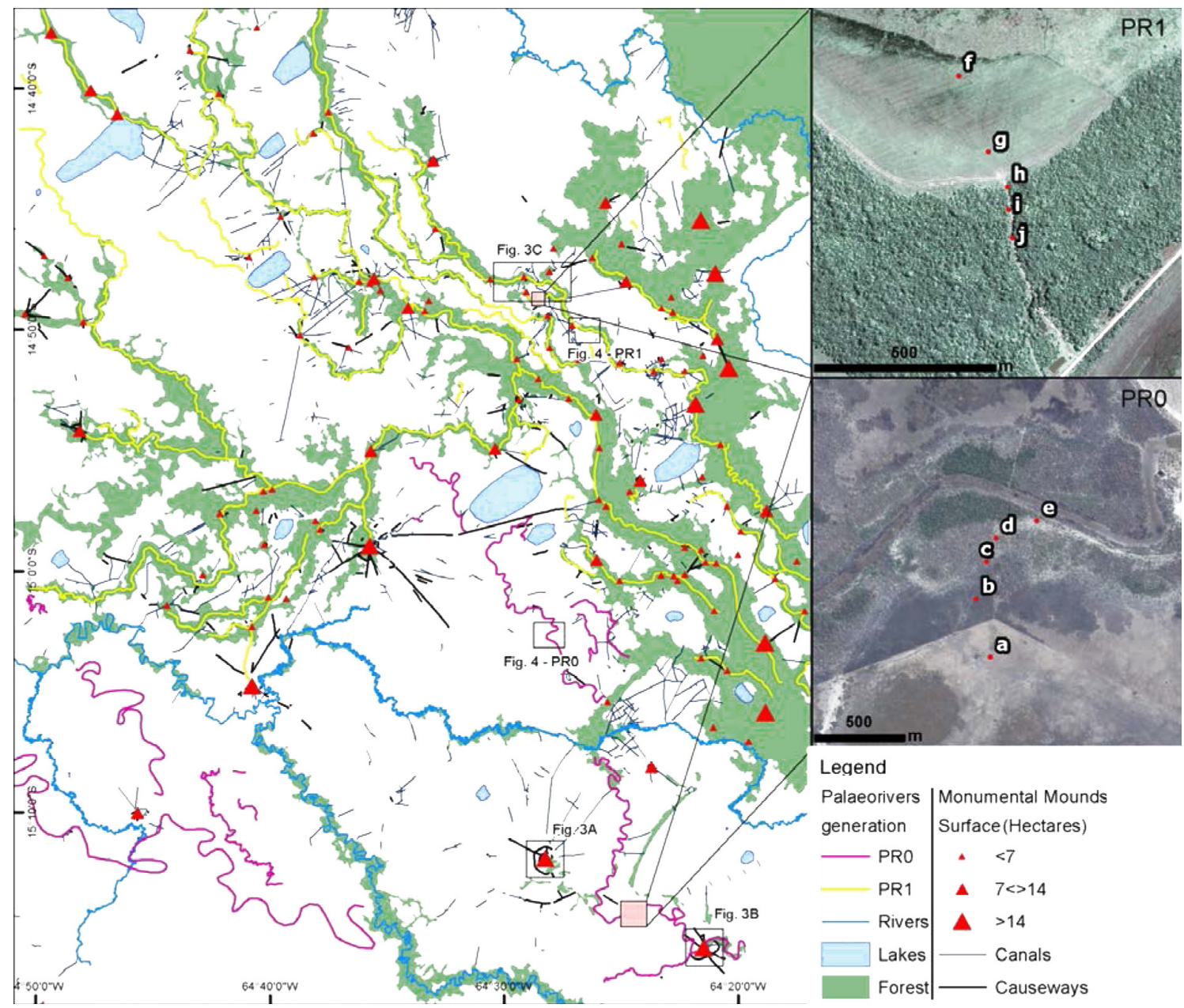

Figure 2. Map of rivers, palaeorivers and pre-Columbian earthworks in the MMR and location of the soil profiles along the two leveebackswamp catenas shown in Figs. 5 and 6.

\section{Methods}

Two transects along levee-backswamp catenas in the MMR were excavated in August and September 2011, in order to assess the spatial distribution of soil properties. The topographic changes along the transects were measured using a digital level Sokkia D50. The topographies along leveebackswamp catenas for PR0 and PR1 palaeorivers were also measured using remote sensing. The remote sensing analysis is based on data retrieved from the ICESat (Ice, Cloud, and land Elevation Satellite) laser altimetry, which operated between 2003 and 2009 with an orbit perpendicular to the Equator. Data have been gathered by the ICESat with high spatial resolution over polar areas and along subvertical paths spaced about $80 \mathrm{~km}$ at the latitude of the LM. For each of these paths, several data sets spaced a few hundreds of metres are available. ICESat has a vertical error of $0.01 \pm 0.04 \mathrm{~m}$ on flat surfaces (Carabajal and Harding, 2006). The elevation is measured on a circular to slightly elliptical surface with a diameter of approximately $55 \mathrm{~m}$ (pink circles in Fig. 4) using the elevation field in the GLA06 data set of the ICESat data release 33, data set L3A, L3G, L3H and L3I (Zwally et al., 2012) The soil profiles were described in the field, photographed and sampled every 5 to $20 \mathrm{~cm}$. The profiles were dug as deep as possible given the depth of the water table. Depths ranged from 0.5 to $2 \mathrm{~m}$. Samples were collected in plastic bags and pre-dried at room temperature before being shipped to Switzerland, where they were dried again in an oven at $60^{\circ} \mathrm{C}$ for 2 days in order to stop microbial activity and allow longer storage (Boone et al., 1999); $30 \mu \mathrm{m}$ thin sections with cover slips were prepared following standard procedures by Geoprep at the Department of Earth Sciences, University of Basel. Grain size distribution was measured with a Malvern Mastersizer Hydro 2000S. Prior to this, about $2 \mathrm{~g}$ of material from each sample was treated with $30 \% \mathrm{H}_{2} \mathrm{O}_{2}$ in order to remove organic matter and then diluted in $15 \mathrm{~mL}$ of dispersing solution ( $3.3 \mathrm{~g}$ sodium hexametaphosphate $+0.7 \mathrm{~g}$ sodium carbonate per $1000 \mathrm{~mL}$ ). Organic carbon was measured with a Vario MACRO $\mathrm{C} / \mathrm{N}$ 


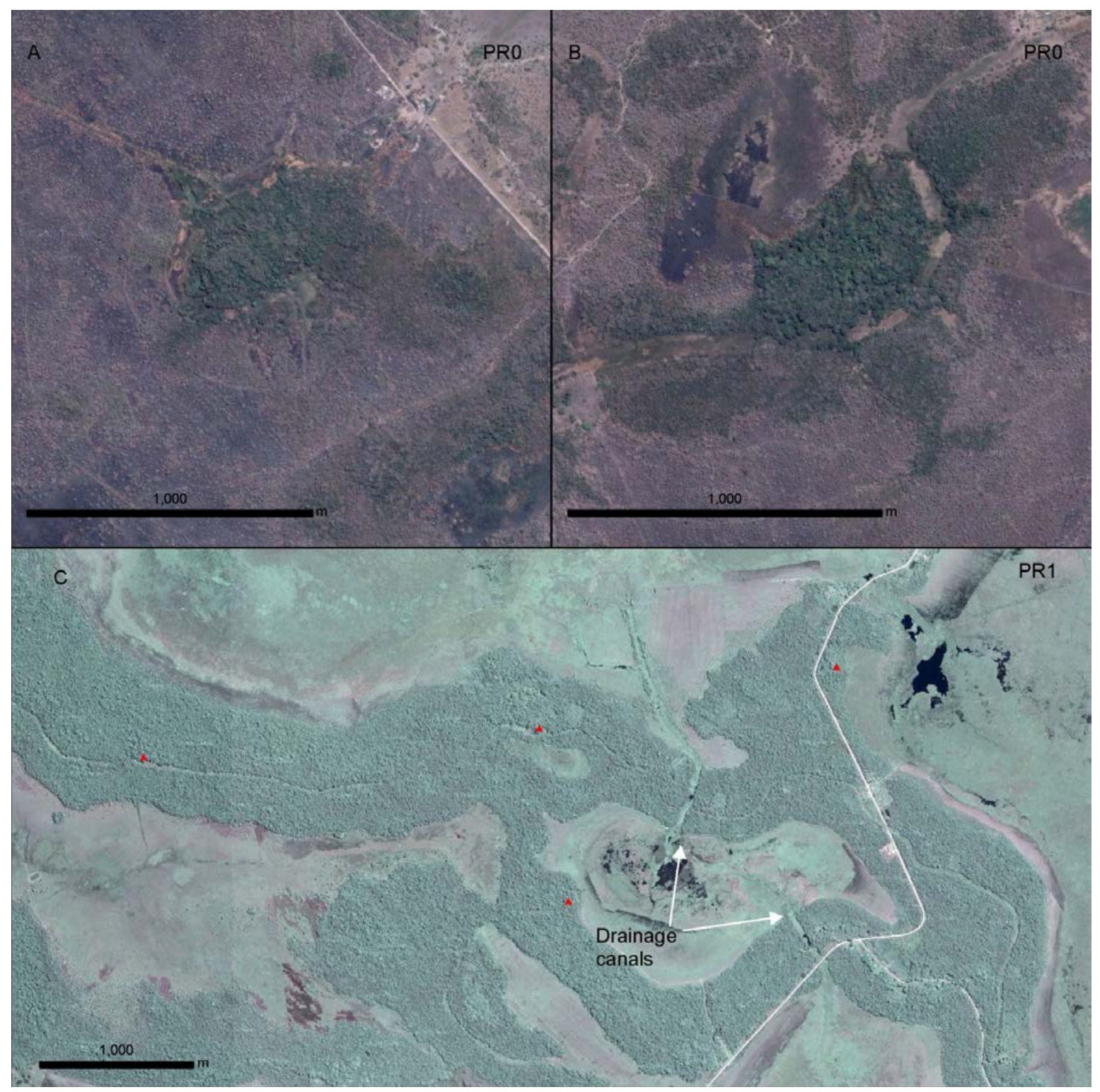

Figure 3. Vegetation over the mounds vs. vegetation over levees. In PR0, (a) and (b), densely forested mounds are easily discernible from their surroundings covered by savannah or sparse forest; while in PR1, (c), the forest growing on the mounds (red triangles) is hardly differentiable from the forest growing on the rest of the levees.

analyser. $\mathrm{C} / \mathrm{N}$ analysis was performed after carbonates had been removed with $\mathrm{HCl}$; glutamic acid was utilized as standard. The $\mathrm{pH}$ was measured in a saline solution of $25 \mathrm{~mL}$ of $0.01 \mathrm{M} \mathrm{CaCl}_{2}$ to which approximately $10 \mathrm{~g}$ of dried and mortared soil were added and then stirred. After letting the mixture settle for $2 \mathrm{~h}$ the $\mathrm{pH}$ was measured in the supernatant solution with a glass electrode. The concentration of exchangeable cations $\mathrm{Ca}^{2+}, \mathrm{Mg}^{2+}, \mathrm{K}^{+}, \mathrm{Na}^{+}, \mathrm{Al}^{+}$, and $\mathrm{Mn}^{2+}$ was measured in an atomic absorption spectrometer Analytik Jena ZEEnit 700P. Prior to this measurement, $5 \mathrm{~g}$ from each sample were mixed with $100 \mathrm{~mL}$ of $1 \mathrm{M}$ Ammonium nitrate $\left(\mathrm{NH}_{4} \mathrm{NO}_{3}\right)$, shaken overnight on a horizontal shaker and then filtered with a pleated filter. The effective cation exchange capacity $\left(\mathrm{CEC}_{\text {eff }}\right)$ is the quantity of cations $\left(\mathrm{Ca}^{2+}, \mathrm{Mg}^{2+}, \mathrm{K}^{+}\right.$, $\mathrm{Na}^{+}, \mathrm{Al}^{+}$, and $\mathrm{Mn}^{2+}$ ) available for exchange in the soil solution at the actual $\mathrm{pH}$ in the soil. $\mathrm{CEC}_{\text {eff }}$ ) is expressed in mmolc $\mathrm{kg}^{-1}$ : millimole cations per $\mathrm{kg}$. The percentage of the concentration of basic cations $\left(\mathrm{Ca}^{2+}, \mathrm{Mg}^{2+}, \mathrm{K}^{+}\right.$and $\left.\mathrm{Na}^{+}\right)$ on the total $\mathrm{CEC}_{\mathrm{eff}}$ is defined as the base saturation (BS).

\section{Results}

The observation of remote sensing imagery shows that the vegetation growing on PR0 palaeorivers differs from the 


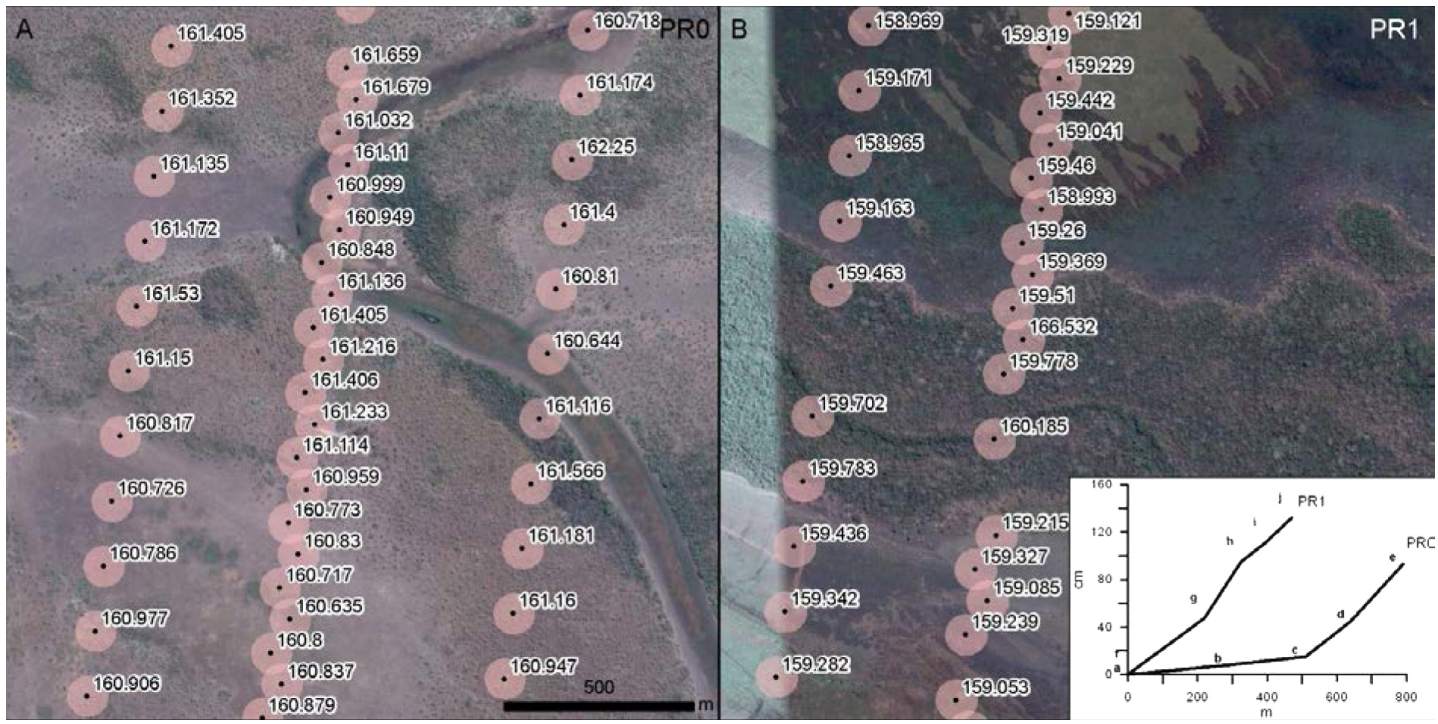

Figure 4. Elevation on the terrain as measured by ICESat across PR0 levee (a) and PR1 (b). Pink circles represent the footprint of the laser pulse; the number is the elevation above the sea level as measured by the first peak in the received signal, thus indicating the elevation of the lowest reflecting surface within the footprint. In the inset the two topographic profiles along the studied catenas measured with a digital level.

vegetation on PR1, confirming field observations. Forested areas are denser in PR1 than in PR0, they are separated from the savannah by sharp boundaries and cover all the upper part of the levees homogenously (Fig. 3). Most of the PR0 levees are covered by savannah vegetation, with abundant Copernicia palms; the forest is relegated to small parts of these levees. The PR0 levees are generally less elevated, with respect to the savannah surrounding them, than the PR1 levees (Fig. 4). Topographic profiles measured in the field with a digital level confirm this observation.

Interestingly, most of the densely forested parts of the older PR0 levees overlap with pre-Columbian monumental mounds (Fig. 3a and b). These PR0 monumental mounds were surveyed in 2006 and 2007. The survey revealed that their shape differs from that of the monumental mounds normally found on PR1 levees. These mounds cover a larger area than PR1 mounds but, in general, are less elevated. The PR0 mound in Fig. 3a covers an area of 17 ha, but reaches a height of only a couple of metres above the savannah.

All soil profiles (Fig. 5), both in PR0 and PR1, are characterized by the absence of soil skeleton, poor sorting of grain size and very little evidence of layering. Table 1 summarizes the field observations of all the soil profiles.

In the PR0 sediments, the sand fraction is quite small in the whole transect, with a mean of $6 \%$ sand (Fig. 7). The average amount of clay in the PR0 sediments is $11 \%$. With a mean percentage of $83 \%$, silt is the predominant size of particles in PR0. The profiles are quite homogenous here, with no sharp changes in grain size distribution among different horizons. On the other hand, the sediments in the PR1 region show a more diverse grain size distribution than in PR0. In PR1 grain size increases with depth in all profiles, except for profile $j$.
In general, the sand content is higher than in the PR0 region, with an average sand fraction of $33 \%$ in the overall transect. The first feature we noticed while digging the profiles was that soil compactness is, in general, much higher in the PR0 sediments than in the PR1 deposits.

The $\mathrm{pH}$ values in the savannah are low in both areas, but savannah soils in the PR0 area have lower values ( $\mathrm{pH}$ ranging from 3.7 to 4.1 ) than the savannah soils in the PR1 area ( $\mathrm{pH}$ ranging from 4.3 to 5.7). This difference in $\mathrm{pH}$ in the savannah soils between the two areas has a big influence on $\mathrm{Al}^{3+}$ solubility. The highest $\mathrm{pH}$ values are found in the levees of PR0 and are associated with high concentration of exchangeable $\mathrm{Na}^{+}$. The $\mathrm{CEC}_{\text {eff }}$ is high in both transects; as could be expected, a direct correlation between $\mathrm{pH}$ and $\mathrm{CEC}_{\text {eff }}$ can be observed. However, important differences between PR0 and PR1 exist regarding the shares of different cations that form the total $\mathrm{CEC}_{\text {eff. }}$ Savannah soils show $\mathrm{CEC}_{\text {eff }}$ values ranging from $62 \mathrm{mmol}_{\mathrm{c}} \mathrm{kg}^{-1}$ (profile a, $40 \mathrm{~cm}$ ) to $164 \mathrm{mmol}_{c} \mathrm{~kg}^{-1}$ (profile $\mathrm{b}, 60 \mathrm{~cm}$ ). Soils in the PR0 levee reach a $\mathrm{CEC}_{\text {eff }}$ of $446 \mathrm{mmol}_{\mathrm{c}} \mathrm{kg}^{-1}$ (profile e, $100 \mathrm{~cm}$ ) (Fig. 4). However, $\mathrm{CEC}_{\text {eff }}$ in the topmost part of the PR0 profiles is almost exclusively constituted by $\mathrm{Al}^{3+}$ (caused by low $\mathrm{pH}$ values; profiles a, b) or $\mathrm{N}^{\mathrm{a}+}$ (causing high $\mathrm{pH}$ values; profiles $\mathrm{c}-\mathrm{e}$ ). The toxic effect of high $\mathrm{Al}^{3+}$ can be mitigated by higher concentrations of $\mathrm{Ca}^{2+}$, but this does not happen in the savannah of PR0 where $\mathrm{Ca} / \mathrm{Al}$ ratios are far lower (Fig. 8). Base saturation (BS) in the levee of PR0 sediments is considerably higher (profiles c, d and e), yet here very high $\mathrm{Na}^{+}$values are present throughout the profiles, which reflect the high $\mathrm{pH}$ values. The percentage of exchangeable sodium (ESP) in the PR0 levee ranges from $27 \%$ (profile c, $10 \mathrm{~cm}$ ) to $89 \%$ (profile e, $60 \mathrm{~cm}$ ) and, in general, ESP values classify these 
Table 1. Soil profiles and diagnostic horizons based on FAO-WRB (2006), PR0: a, Umbric Gleysol; b, Umbric Gleysol; c, Sodic Luvisol; d, Sodic Luvisol; e, Sodic Luvisol; f, Mollic Gleysol; g, Mollic Gleysol; h, Stagnic Gleysol; i, Endosodic Stagnic Gleysol; j, Cambisol. See also Figs. 5, 6 and 7.

\begin{tabular}{|c|c|c|c|}
\hline $\begin{array}{l}\text { Profile } \\
\text { PR0 }\end{array}$ & Depth $(\mathrm{cm})$ & Horizon & Diagnostic horizons, properties and materials \\
\hline a & $0-20$ & $\mathrm{Ah}$ & $\begin{array}{l}\text { Dark, silt, very moist, dense, distinct but undulated border to underlying horizon, roots from grasses growing on top. } \\
\text { Umbric. }\end{array}$ \\
\hline $\mathrm{a}$ & -45 & Ah\&Bg & Dark tongues for upper horizon in grey material with yellow mottling, silt, very moist, dense. Umbric/Gleyic \\
\hline a & -50 & $\mathrm{Bg}$ & Yellow mottling in grey matrix, silt loam, very moist, dense. Gleyic \\
\hline $\mathrm{b}$ & $0-40$ & Ah1 & Dark, silt loam, very moist, dense, roots from grasses growing on top. Umbric. \\
\hline $\mathrm{b}$ & -70 & $\mathrm{Bg}$ & Yellow mottling, silt, very moist, very dense. Gleyic. \\
\hline $\mathrm{c}$ & $0-15$ & Ahn & $\begin{array}{l}\text { Dark, silt loam, slightly moist, undulated and indistinct boundary, roots from grasses and shrubs growing on top, } \\
\mathrm{Na}^{+}>15 \% \text {. Sodic/Mollic }\end{array}$ \\
\hline $\mathrm{c}$ & -40 & AhnBgn & Yellow mottling in dark matrix, silt loam, moist, dense, high root penetration, $\mathrm{Na}^{+}>15 \%$. Sodic \\
\hline $\mathrm{c}$ & -80 & Btgn & Yellow mottling in grey matrix, silt, moist, dense, some fluvial layering, clay cutans, reduced, $\mathrm{Na}^{+}>15 \%$. Sodic/Gleyic \\
\hline $\mathrm{c}$ & -105 & Bgn & Yellow, silt, slightly moist, sesquioxides and Mn concretions, some fluvial layering, $\mathrm{Na}^{+}>15 \%$. Sodic/Gleyic \\
\hline $\mathrm{d}$ & $0-10$ & Ahn & Slightly dark, silt, dry, dense, strong roots from grasses, bushes and small trees, $\mathrm{Na}^{+}>15 \%$. Sodic. \\
\hline $\mathrm{d}$ & -25 & En & Grey, silt loam, dry, $\mathrm{Na}^{+}>15 \%$. Sodic/Albic \\
\hline $\mathrm{d}$ & -100 & Btn & $\begin{array}{l}\text { Yellow/brown, silt, dry, dense, blocky structure, aggregated surfaces coated with clay cutans, Mn concretions, } \\
\mathrm{Na}^{+}>15 \% \text {. Sodic }\end{array}$ \\
\hline $\mathrm{d}$ & -160 & Btgn & Grey with little yellow mottling, silt, moist, clay cutans, $\mathrm{Na}^{+}>15 \%$. Sodic/Gleyic \\
\hline $\mathrm{e}$ & $0-10$ & Ahn & Slightly dark, silt, dry, very dense, strong roots from bushes and trees growing on top, $\mathrm{Na}^{+}>15 \%$. Sodic \\
\hline $\mathrm{e}$ & -30 & En & Grey, silt loam, dry, dense, border to other horizons is indistinct, $\mathrm{Na}^{+}>15 \%$. Sodic/Albic. \\
\hline $\mathrm{e}$ & -160 & Btn & Yellow/light brown, silt, dry, dense with density slightly decreasing with depth, clay cutans, $\mathrm{Na}^{+}>15 \%$. Sodic \\
\hline $\mathrm{e}$ & -200 & Btgn & $\begin{array}{l}\text { Light brown with yellow mottling, silt, slightly moist, dense, some fluvial layering, few clay cutans, } \mathrm{Na}^{+}>15 \% \text {. } \\
\text { Gleyic/Sodic }\end{array}$ \\
\hline \multicolumn{4}{|l|}{ PR1 } \\
\hline $\mathrm{f}$ & $0-20$ & $\mathrm{Ah}$ & $\begin{array}{l}\text { Very dark, silt loam, slightly moist, undulated and indistinct boundary to underlying horizon, roots from grasses growing } \\
\text { on top. Mollic. }\end{array}$ \\
\hline $\mathrm{f}$ & -40 & $\mathrm{Ah} \& \mathrm{Bg}$ & $\begin{array}{l}\text { Dark tongues for upper horizon in grey material with yellow mottling, silt loam, slightly moist, very dense, few roots. } \\
\text { Mollic/Gleyic. }\end{array}$ \\
\hline $\mathrm{f}$ & -100 & $\mathrm{Bg}$ & $\begin{array}{l}\text { Orange and yellow mottling in grey matrix, sandy loam, moist, loose, some organic matter, washed in from root canals. } \\
\text { Gleyic. }\end{array}$ \\
\hline $\mathrm{g}$ & $0-20$ & $\mathrm{Ah}$ & Dark, silt loam, dry, dense, undulated boundary to underlying horizon, roots from grasses growing on top. Mollic. \\
\hline $\mathrm{g}$ & -40 & $\mathrm{Ah} \& \mathrm{Bg}$ & $\begin{array}{l}\text { Dark tongues for upper horizon in grey material with yellow mottling, silt loam, slightly moist, dense, few roots. } \\
\text { Mollic/Gleyic. }\end{array}$ \\
\hline $\mathrm{g}$ & -70 & $\mathrm{Bg}$ & Orange and yellow mottling in grey matrix, sandy loam, moist, loose, few roots. Gleyic. \\
\hline $\mathrm{h}$ & $0-10$ & $\mathrm{Ah}$ & Slightly dark, silt loam, dry, dense, strong roots from trees and shrubs. \\
\hline $\mathrm{h}$ & -60 & $\mathrm{Bg} 1$ & $\begin{array}{l}\text { Grey with some yellow mottling, silt loam, dry, very dense, some humus and roots penetrating from overlying horizon, } \\
\text { waterlogged from water coming from top. Stagnic. }\end{array}$ \\
\hline $\mathrm{h}$ & -100 & $\mathrm{Bg} 3$ & $\begin{array}{l}\text { Orange mottled horizon with grey spots along root canals, sandy loam, dry, dense, some organic matter washed in along } \\
\text { root canals, many roots. Gleyic. }\end{array}$ \\
\hline $\mathrm{h}$ & -160 & $\mathrm{Bg} 3$ & Orange mottled horizon with grey spots along root canals, sandy loam, slightly moist, loose, many roots. Gleyic. \\
\hline $\mathrm{i}$ & $0-15$ & A & Grey, silt loam, dry, loose, distinct boundary to underlying horizon, strong roots from shrubs and trees, little humus. \\
\hline $\mathrm{i}$ & -70 & $\mathrm{Bg} 1$ & $\begin{array}{l}\text { Grey with some dark Mn concretions, silt loam, dry, very dense, waterlogged from water coming from the top, slightly } \\
\text { undulated and indistinct boarder to underlying horizon, much fewer roots than overlying horizon. Stagnic. }\end{array}$ \\
\hline $\mathrm{i}$ & -160 & $\mathrm{Bg} 2$ & $\begin{array}{l}\text { Orange mottled horizon with grey spots along root canals, sandy loam, slightly moist, loose, some burnt clay at various } \\
\text { depths, Fe concretions with diameters up to } 15 \mathrm{~cm} \text {, few roots, } \mathrm{Na}^{+}>15 \% \text {. Endosodic/Gleyic. }\end{array}$ \\
\hline j & $0-10$ & $\mathrm{Ah}$ & Dark, silt loam, dry, loose, strong roots from trees and shrubs, indistinct boarder to underlying horizon. \\
\hline $\mathrm{j}$ & -140 & $\mathrm{Bw}$ & $\begin{array}{l}\text { Homogenous orange, silt loam, dry, some roots, some charcoal (at } 15 \mathrm{~cm} \text { and } 60 \mathrm{~cm} \text { ), indistinct boarder to underlying } \\
\text { horizon. Cambic }\end{array}$ \\
\hline $\mathrm{j}$ & -250 & $\mathrm{Bg}$ & $\begin{array}{l}\text { Orange mottled horizon with grey spots along root canals and generally grey near the bottom, silt loam, slightly moist, } \\
\text { loose, manganese concretions, some roots. Gleyic }\end{array}$ \\
\hline $\mathrm{j}$ & -260 & fAh & Dark palaeosol, silt loam. \\
\hline
\end{tabular}

soils as high to extremely high hazard for crop growth (Fitzpatrick, 1986).

There are radical differences concerning $\mathrm{BS}$ and $\mathrm{Ca} / \mathrm{Al}$ ratios when comparing the soils in the two areas. In the PR1 soils, BS never falls below $61 \%$ (profile h, $20 \mathrm{~cm}$ ) whilst in PR0 BS can be as low as $35 \%$ (profile a, $10 \mathrm{~cm}$ ), and Ca / Al ratios in the PR1 topsoils are about 10 times higher than in PR0. According to Cronan and Grigal (1995), a low Ca / Al ratio implies a high risk of $\mathrm{Al}$ stress for a forest ecosystem and an even higher risk for crop growth. In PR1, ESP is relatively low throughout the whole transect, with the exception of profile i where ESP ranges from $19 \%$ (depth of $50 \mathrm{~cm}$ ) 

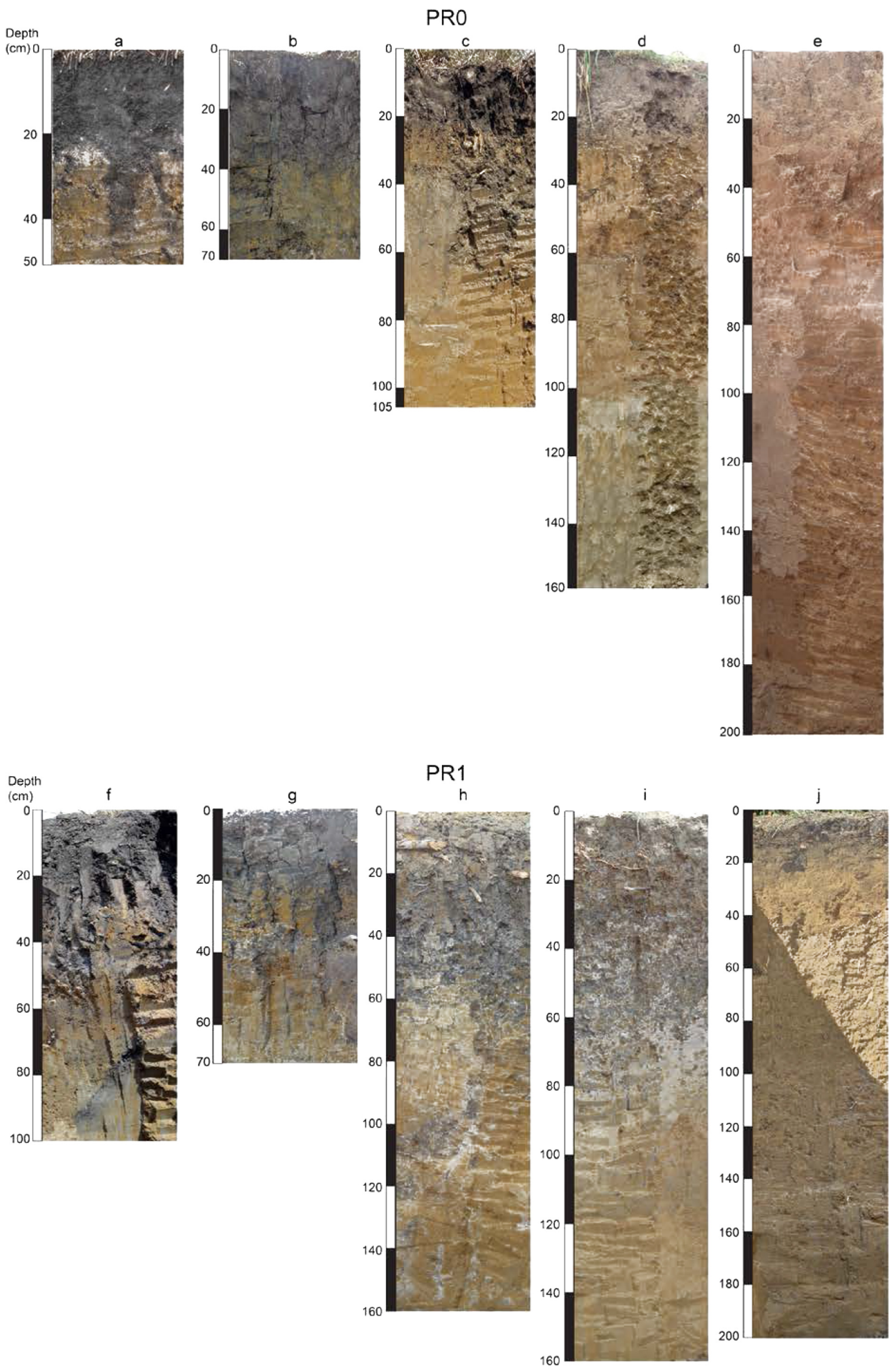

Figure 5. Photos of the profiles. Some differences in colour can be due to differences in natural light and exposure. See Table 1 for description. 


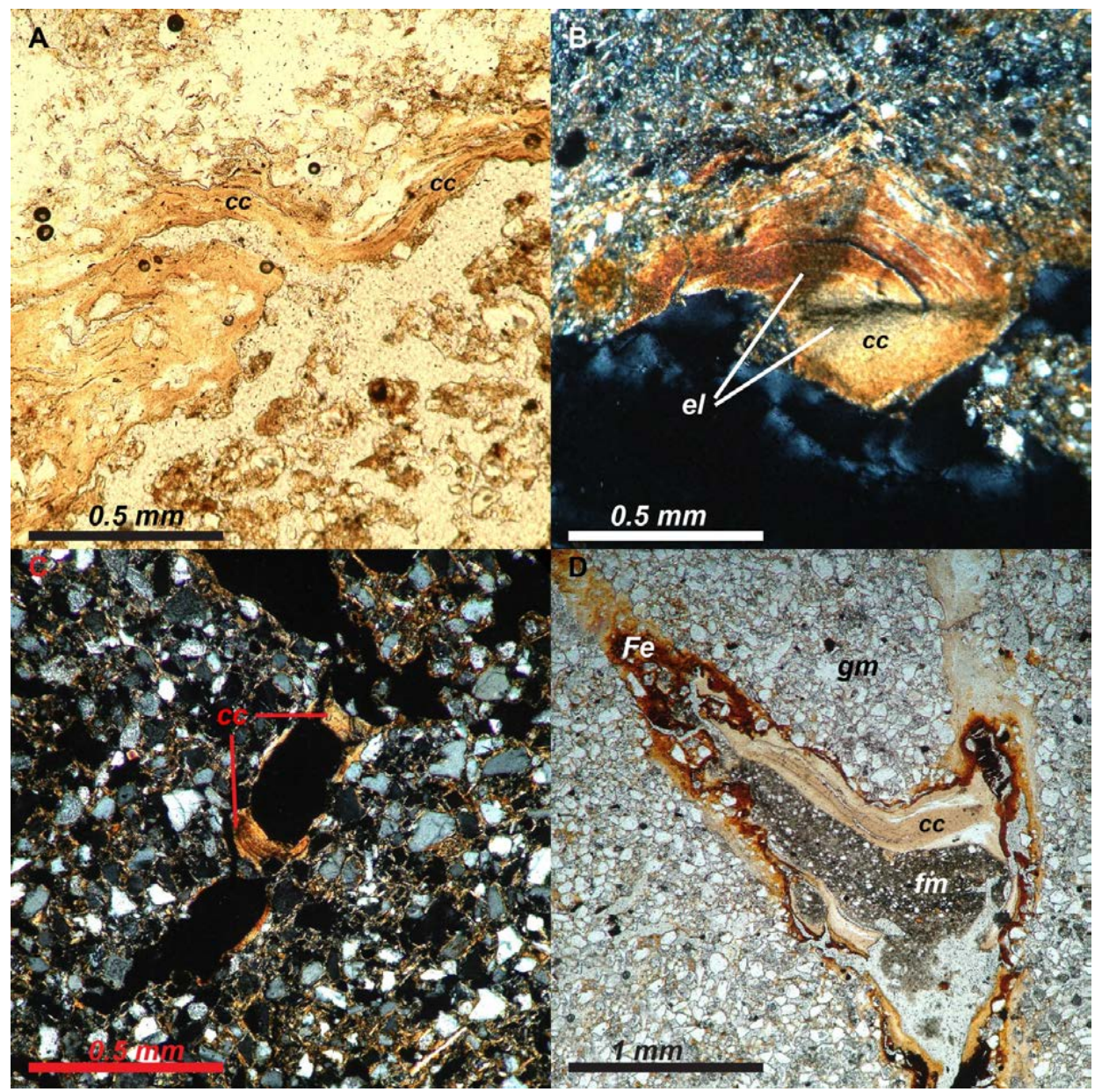

Figure 6. Thin sections of (a) clay coatings in profile e at a depth of $70 \mathrm{~cm}$ (PR0), PPL. (b) Layered clay with extinction lines in profile e at a depth of $130 \mathrm{~cm}$ (PR0), XPL. (c) One of the few clay accumulations found in PR1 (profile j, depth of $100 \mathrm{~cm}$ ), XPL. (d) Root canal with iron hypocoating, clay coating and dense incomplete infilling of finer material in profile h, depth of $80 \mathrm{~cm}$ (PR1), PPL. cc: clay coatings, el: extinction lines, ab: air bubbles in the mounting medium, gm: greyish matrix, Fe: iron hypo-coating, fm: fine-grained matrix.

to $49 \%(100 \mathrm{~cm})$. The PR1 levee is covered by a dense forest. In PR0 there is hardly any forest; the vegetation here is savannah, dotted with $\mathrm{Na}^{+}$tolerant Copernicia palms (García Miragaya et al., 1990). This is consistent with the fact that few plants can grow on soils with high $\mathrm{Na}^{+}$concentrations. Looking at the PR1 area as a whole, conditions for plant growth are favourable. Moreover plant essential cations $\left(\mathrm{Ca}^{2+}, \mathrm{Mg}^{2+}, \mathrm{K}^{+}\right)$are available in far higher quantities in PR1 than in PR0.

Based on the FAO WRB (2006), savannah soils from the PR0 catena are classified as Umbric Gleysol (profiles a and b); these savannah soils are characterized by having abundant redoximorphic features and by having very dark $\mathrm{Ah}$ horizons, with $\mathrm{C}_{\text {org }}$ content of 3 and $6 \%$, respectively and $\mathrm{BS}<50$. Even during the dry season, at the time the pits were dug, savannah PR0 profiles were saturated with water. PR0 levee soils (profiles c, d and e) are classified as Sodic Luvisol because of very well developed Bt horizons and high concentrations of exchangeable $\mathrm{Na}^{+}$. Clay coating is visible in thin sections at depths of 70 and $130 \mathrm{~cm}$ in profile e (Fig. 5i and ii). E horizons are distinguishable in profiles $\mathrm{d}$ and $\mathrm{e}$. Some redoximorphic features are recognizable at the bottom of these profiles. Although values of $\mathrm{Na}^{+}$are very high, we do not classify these soils as Solonetz because the characteristic natric horizon with columnar structure is lacking. Profiles $\mathrm{f}$ and $\mathrm{g}$ in PR1 are classified as Mollic Gleysol, as $\mathrm{Bg}$ horizons with abundant redoximorphic features are covered by Ah horizons with high $\mathrm{C}_{\text {org }}$ and $\mathrm{BS}>50$.

PR1 savannah soils contained less water than PR0 savannah soils, even though they were dug almost at the same time. Profiles $h$ and i are classified as Stagnic Gleysol because of Fe reduction in the upper part of the subsoil, probably caused by rain waterlogging, and orange mottling in the bottom of the profiles. Profile i is an Endosodic Stagnic Gleysol because in addition to $\mathrm{Fe}$ reduction in the upper part it also has more than $15 \%$ exchangeable $\mathrm{Na}^{+}$between 50 and $100 \mathrm{~cm}$. 


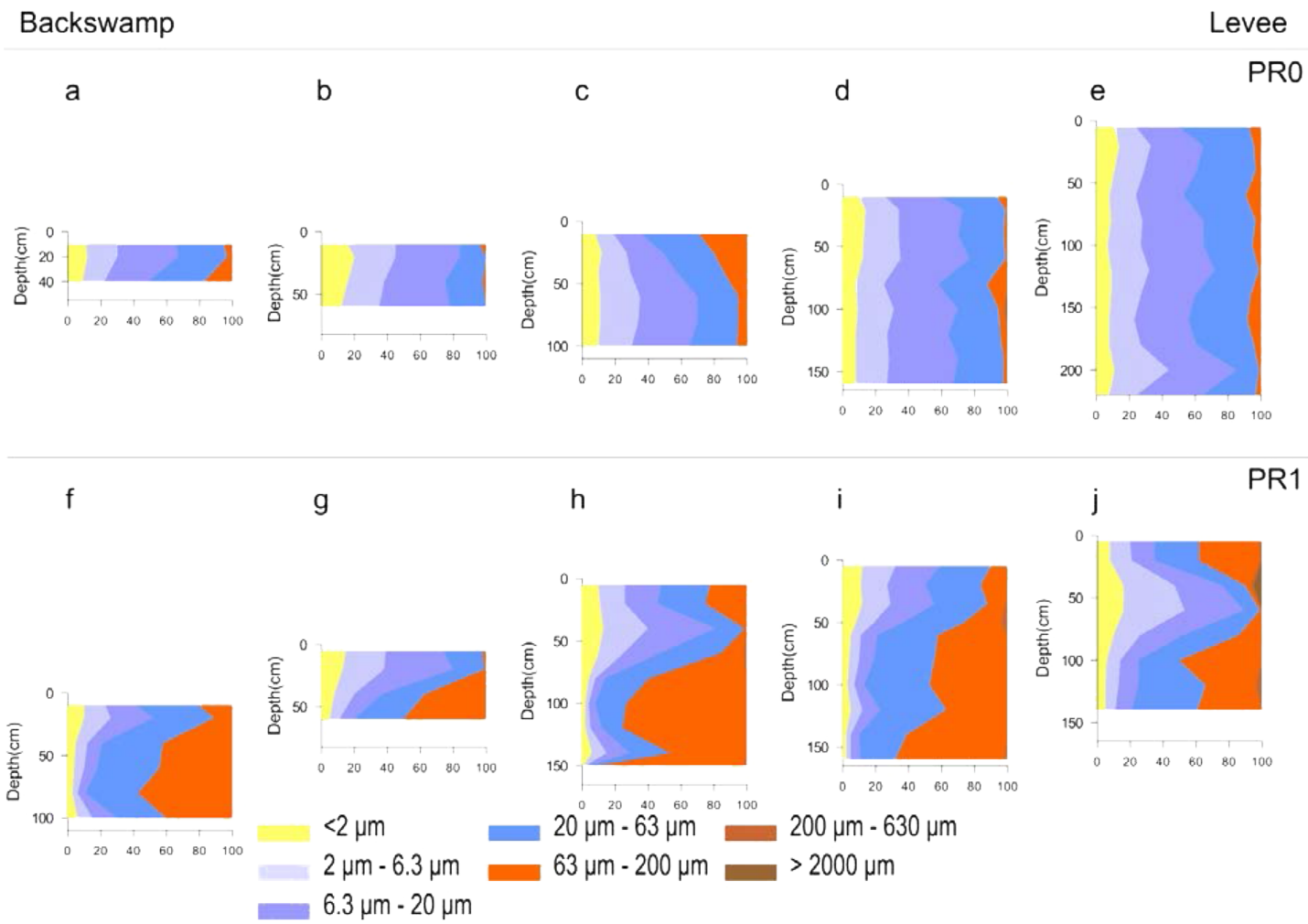

Figure 7. Grain size distribution along the soil profiles of the PR0 and PR1 transects.

Profile $\mathrm{j}$ is classified as Cambisol due to its little development: no clear horizon differentiation is discernable. However, a few examples of clay illuviation are recognizable in the B horizon (Fig. 6c) and some orange mottling at the bottom of the profile.

\section{Discussion}

Soils in the southwestern LM have been described through the analysis of two levee-backswamp catenas. The soils from these two catenas represent most of the soils found in the southwestern LM, where sediments belong either to the midto late Holocene, deposited palaeo Grande River fan (PR1), or to a Late Pleistocene-early Holocene palaeoriver system (PR0) (Lombardo et al., 2012; Plotzki, 2013).

The comparison between the PR0 and PR1 catenas shows that PR0 and PR1 areas differ in important variables which determine their agricultural potential.

The PR1 sediments have clearly better physical properties that allow good plant growth, compared to the compact profiles in the PR0 area. The higher fraction of sand in the PR1 area creates better permeability, better ventilation and facilitates root penetration, while nutrient and water holding capacity are still adequate for agriculture (Fitzpatrick, 1986). The difference in granulometry between PR 0 and PR 1 is probably due to different depositional environments. PR0 formed between the Late Pleistocene and the mid-Holocene, when rivers had less energy; therefore, PR0 rivers' overflow deposited mostly thin layers of fine silts and clays. PR1 formed in the mid- to late Holocene following a shift towards increased discharge which permitted the transport and deposition of coarser material. The levee-backswamp boundaries are far sharper in the case of the PR1 levees than in the PR0 levees, probably due to a faster and more recent deposition of the PR1 sediments (Cazanacli and Smith, 1998).

Important limiting factors for crop growth exist in the savannah and levees of PR0 which are not present in PR1. The PR0 catena is characterized by the transition from Umbric Gleysol with high exchangeable $\mathrm{Al}^{3+}$ in the savannah to Sodic Luvisol with high exchangeable $\mathrm{Na}^{+}$in the levee. The PR1 catena is characterized by the transition from Mollic Gleysol to Cambisol with high $\mathrm{CEC}_{\text {eff }}$ and BS. These Mollic Gleysols also have high levels of exchangeable $\mathrm{Al}^{3+}$, although less than in the PR0 savannah, and they have a higher base saturation. In the savannah of PR0, $\mathrm{Al}^{3+}$ toxicity is the most limiting factor for agriculture, while in the PR1 savannah the toxicity of $\mathrm{Al}^{3+}$ is counterbalanced by $\mathrm{Ca}^{2+}$. In the PR0 savannah most crop plants, including maize and manioc, would be unable to grow even during the dry season because of low BS and low Ca / Al ratios (Roy et al., 1988; Delhaize and Ryan, 1995). On the levee of PR0, exchangeable sodium exceeded the threshold of $15 \%$ throughout the whole profile, representing a high to extremely high hazard for crops (Abrol et al., 1988). This is particularly important for maize and 
Backswamp

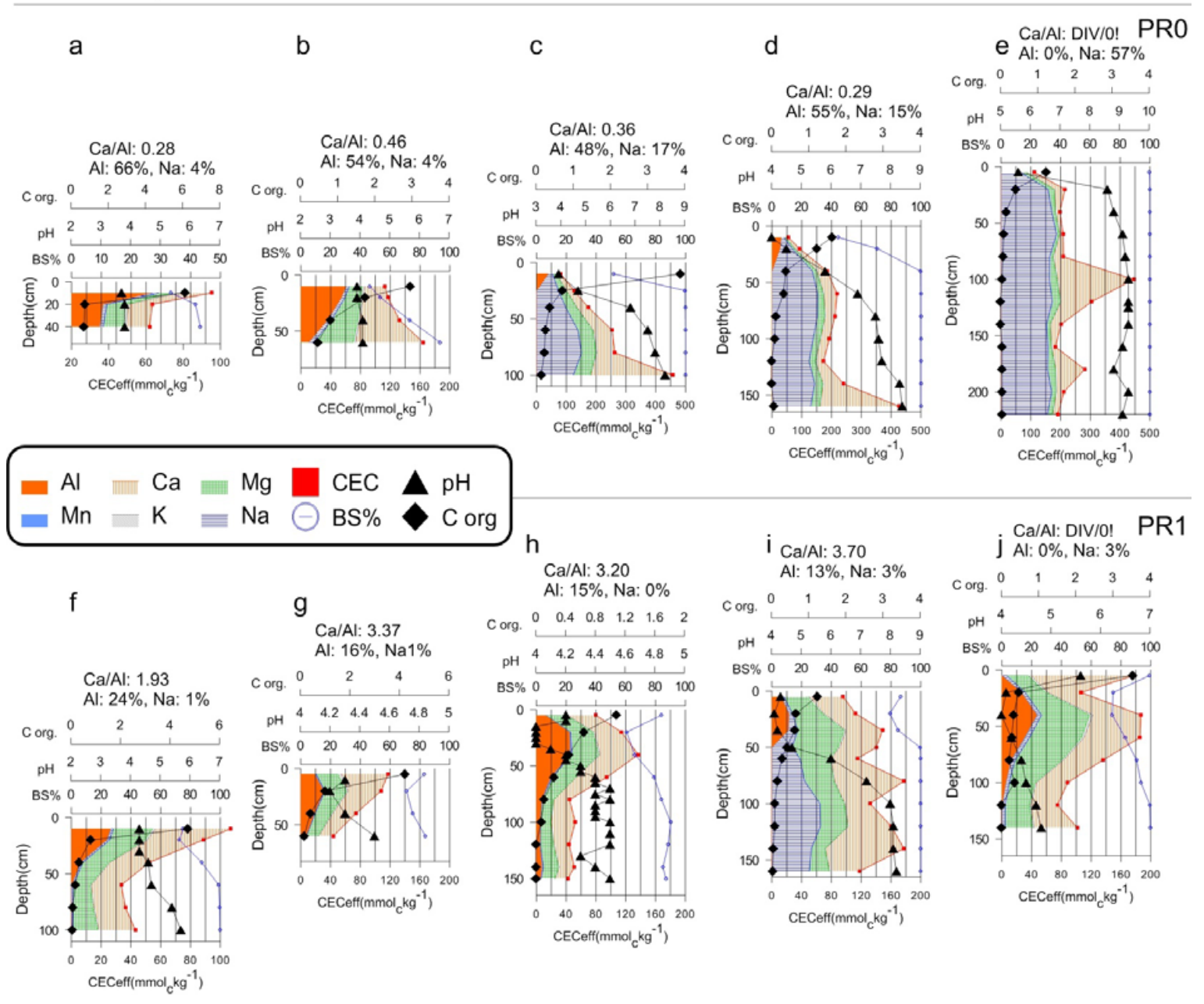

Figure 8. Geochemistry of the soil profiles of the PR0 and PR1 transects.

cassava, which are two of the most important pre-Columbian crops in Amazonia (Arroyo-Kalin, 2012). Both crops are affected by high $\mathrm{Na}^{+}$, with cassava showing a sharp reduction in productivity when $\mathrm{Na}^{+}$saturation is above 2 to $5 \%$ (Fageria et al., 2011).

The differences between the PR0 and PR1 catenas are probably the result of several factors: the difference in the age of the sediments on which they developed, the difference in the mineralogy and salt content of the original deposits and groundwater, and the stronger hydromorphism induced by the water table on PR0 than on PR1. Figure 8 shows a schematic representation of the main processes determining soil properties in PR0 and PR1. Both PR0 and PR1 savannahs are characterized by hydromorphism due to seasonal wet and dry conditions. This is a two-phase process (Van Breemen and Buurman, 2002). During the wet season the rise of the water table in PR0 and the waterlogging in PR1 causes the reduction of $\mathrm{Fe}^{3+}$ to $\mathrm{Fe}^{2+}$, which displaces formerly absorbed cations such as $\mathrm{Ca}^{2+} \mathrm{Mg}^{2+}$ and $\mathrm{K}^{+}$that are mobilized and can be easily lost from the soil. During the dry season the oxidation of $\mathrm{Fe}^{2+}$ to $\mathrm{Fe}^{3+}$ frees $\mathrm{H}^{+}$, which decreases $\mathrm{pH}$. In acid conditions clay minerals are partially destroyed and $\mathrm{Al}^{3+}$ is released in the soil solution. Depending on the dynamics of the floods and the age of the PR0 savannah soils, these become enriched in exchangeable $\mathrm{Al}^{3+}$ and depleted in other cations. The relatively higher amount of exchangeable $\mathrm{Ca}^{2+}$ in the PR1 savannah, compared with PR0, is probably due to the younger age of PR1 sediments. The PR0 levees are quite different from those in PR1. During the dry season, the $\mathrm{NaCl}$ contained in the groundwater rises to the upper part of the levee by capillarity and salt is deposited. Saline soils with abnormally high $\mathrm{pH}$ values have been reported in many areas of the LM, where they are called salitrales (Hanagarth, 1993; Boixadera et al., 2003). Salitrales are known to local people because wild animals and cattle often dig these soils in search of salt. However, in the case of the PR0 levee, salt is not preserved in the sediments. During the rainy season, rainwater infiltrates into the subsoil and washes out $\mathrm{Cl}^{-}$, which 

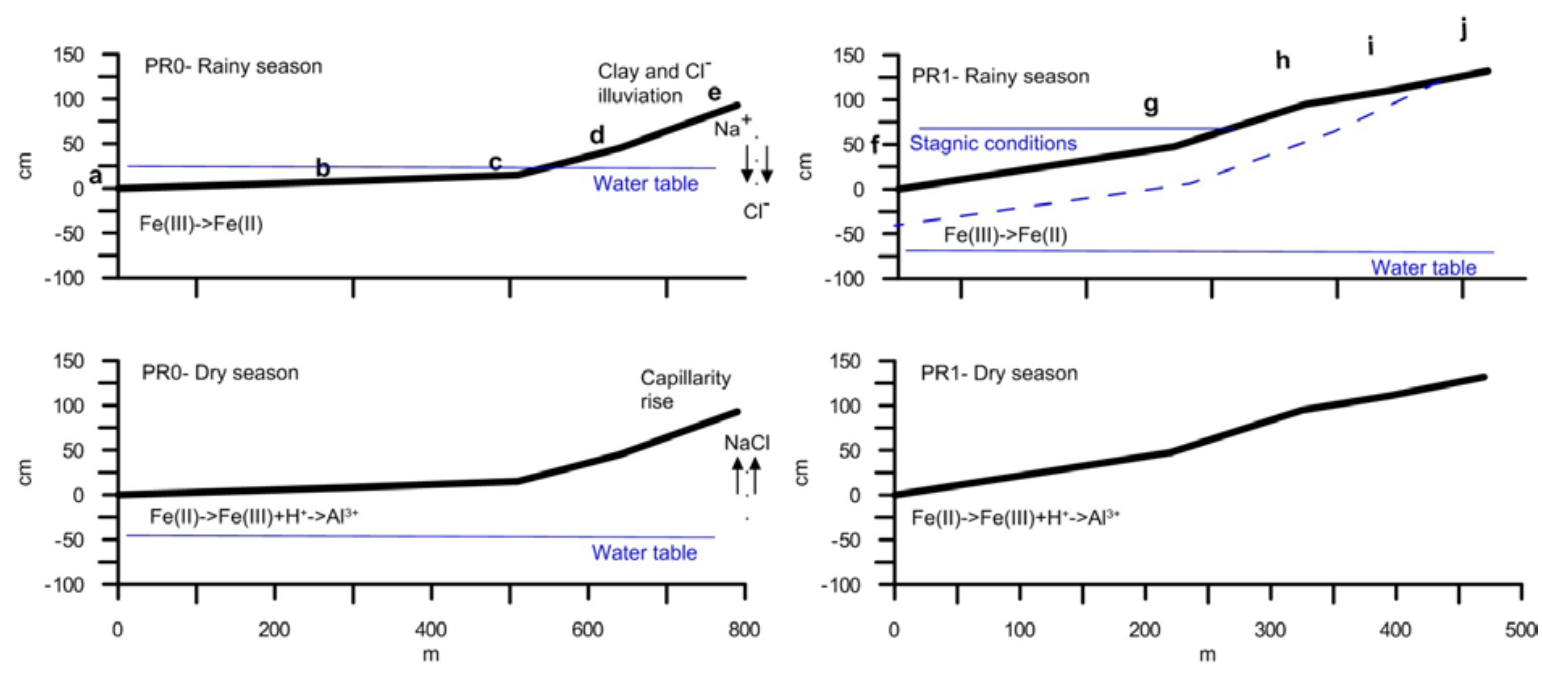

Figure 9. Processes of soil formation in PR0 and PR1. Savannahs in both PR0 and PR1 are seasonally wet and dry, with Fe reduction during the rainy season and Fe oxidation during the dry season. Levees in PR0 are affected by mobility of $\mathrm{Cl}^{-}$and clay which are transported to the B horizon (clay) or deeper $\left(\mathrm{Cl}^{-}\right)$during the rainy season. In PR1 waterlogging is due to local rain, without the contribution of groundwater table rise, causing weak stagnic conditions. During the dry season, the presence of salt-rich groundwater in PR0 causes the capillarity rise of $\mathrm{NaCl}$. The seasonal alternation of capillarity rise of $\mathrm{NaCl}$ and eluviation of $\mathrm{Cl}^{-}$leads to an enrichment of $\mathrm{Na}+$ and the formation of $\mathrm{NaOH}$ with a consequent increase in $\mathrm{pH}$. In PR1 the disappearance of the stagnic conditions during the dry season is followed by Fe oxidation along root canals.

is far more mobile than $\mathrm{Na}^{+}$(Fig. 9). The alternation of $\mathrm{NaCl}$ rise and $\mathrm{Cl}^{-}$translocation leads to the enrichment of the soil with $\mathrm{Na}^{+}$. This $\mathrm{Na}^{+}$enrichment has two important effects on the soil that are clearly visible in profile e: it increases the $\mathrm{pH}$ (profile e reaches $\mathrm{pH}$ 9) and destabilizes the clay aggregates. The latter facilitates clay eluviation from the top of the profile, where the $\mathrm{E}$ horizon forms, and clay illuviation in the Bt horizon, where clay cutans form, even under such basic conditions (Van Breemen and Buurman, 2002). Besides the fact that the PR1 levee is younger than the PR0 one, the most important difference is that the former is not affected by the rise of $\mathrm{NaCl}$ during the dry season, either because the groundwater has no salt or because the water table is too low. Profile i represents the exception, having high values of $\mathrm{Na}^{+}$ in the subsoil below $50 \mathrm{~cm}$. This is probably due to locally high values of $\mathrm{NaCl}$ in the subsoil. With the exception of profile $\mathrm{i}$, soil processes acting in PR1 levees are limited to some hydromorphism caused by water stagnation. Although from a physical point of view conditions in PR1 are good for the formation of a Luvisol, as in PR0, the acidity of the soils in PR1 slows down the eluviation/illuviation process. For this reason, the soils in the PR1 levees are not very well developed.

The sparse vegetation and the abundance of the $\mathrm{Na}^{+}$tolerant Copernicia palm growing on the levees of the PR0 sediments reflect the harsh conditions of PR0 soils. On the contrary, the thick and lush forest growing on the levees of PR1 attests a more favourable setting, where $\mathrm{Na}^{+}$is not an issue.

In the PR0 area, dense forests comparable to the ones growing on PR1 levees are only found on top of the monumental mounds (Fig. 3). This demonstrates how the improved drainage derived from the raising of the mound platform and the addition of $\mathrm{Ca}, \mathrm{P}$, charcoal and the other soil amendments associated with human occupations and middens changed soil properties and the vegetation on these mounds. The enrichment of the mound in PR0 was probably possible thanks to hunting and gathering activities carried out in the surrounding savannah and forest where game, fish and wood were available. It would seem that, at a local scale, people enhanced soil properties; however, this does not change the overall picture. This study provides evidence that sediments deposited by the Grande River in the mid- to late Holocene created in PR1 land far more fertile than the pre-existing soils, which are still present in PR0. The higher density of monumental mounds in PR1 than in PR0 suggests that pre-Columbian settlements and population density in the MMR were strongly influenced by pre-existing environmental constraints and opportunities. It is possible that, as the mounds in PR0 are surrounded by a poorer environment, the population of each mound needed a larger area to sustain itself than in the PR1 area. The fact that the mounds in PR0 are generally less elevated but larger in area than the PR1 mounds could suggest that in the PR0 area, in a contest of poor soils, people performed agriculture on the mound itself. However, detailed surveys accompanied by archaeological excavations are needed in order to understand whether the shape of the mounds in PR0, flatter but wider, responds to the fact that they were used for agriculture. Still, it is not clear how pre-Columbians sustained themselves here. In the MMR there is no evidence of agricultural raised fields, 
which are so abundant in other areas of the LM. Lombardo et al. (2012) have put forward the hypothesis that in the PR1 area, where the highest density of mounds is found, preColumbians increased the extent of the agricultural land by digging canals that speeded up the drainage of the savannah at the end of the rainy season (see examples of drainage canals in Fig. 3c). Alternatively, they could have artificially enhanced soils through intensive slash-and-burn cultivation, as hypothesized for the formation of terra mulata in Brazil (Lehmann et al., 2003; Fraser et al., 2011; Arroyo-Kalin, 2012). However, if slash-and-burn agriculture had been practiced during hundreds of years here, significant quantities of charcoal would be present in the sediments. This is not the case; no large amounts of charcoal or other evidence of enriched soil has been found along the PR1 levees. It would appear that at least part of the forest was used as a reservoir for game, medicinal plants, fire wood, construction materials and other activities that did not involve deforestation. This is consistent with what was found by Whitney et al. (2013) in their analysis of the sediments of lake San José, in the MMR, where pollen assemblage suggests that the amount of forested area in the MMR during pre-Columbian times was similar to the present day. Nevertheless, archaeological excavations (Bruno, 2010; Dickau et al., 2012) and pollen profiles from lakes inside the MMR (Whitney et al., 2012) show that maize production was widespread in this region. Isotopic analysis of bones of domestic duck unearthed during archaeological excavation at Loma Salvatierra revealed that ducks were fed on maize (T. Hermenegildo, personal communication, 2014), indicating high availability of maize. It would seem that the only remaining evidence of past agricultural activity in the MMR is the drainage infrastructure. We propose that agriculture took place mostly in the drained savannah, where, if fire were used, it would have produced only ashes and perhaps some microcharcoal. The thin section in Fig. 5d, profile h, shows a change from clay illuviation into a root canal to infilling of the canal with material from above. This could indicate anthropogenic disturbance resulting from agricultural activity taking place at the current forest-savannah boundary. In addition, agricultural activity could explain the difference between profile $\mathrm{i}$ and profile $\mathrm{j}$. These two profiles strongly differ in terms of hydromorphism of the B horizon, with stagnic conditions present in i but absent in $\mathrm{j}$ (Fig. 5). It could be that the stagnic conditions in $\mathrm{i}$ are caused by a local change in topography which causes localized waterlogging. However, the forest that covers the PR1 levee at the location of the profile $i$ is not different from the forest found at the location $\mathrm{j}$, suggesting that the stagnic conditions seen in $\mathrm{i}$ are inherited from the past. Two possible, nonexclusive scenarios can cause high permeability, which induces stagnic conditions in the i profile's topmost sediments: (i) it could be the result of the past presence of savannah which left many root canals through which the water can easily permeate, indicating that the ancient forestsavannah ecotone was located between $\mathrm{i}$ and $\mathrm{j}$ or (ii) it could be that pre-Columbian agriculture caused erosion at the centre of the levee and the formation of a more permeable colluvium towards the savannah. Both these scenarios are compatible with the drainage hypothesis proposed by Lombardo et al. (2012) where (i) the opening of the drainage canals drained the upper part of the savannah; (ii) cultivation took place on the drained savannah and also on part of the former forested levee; (iii) agriculture caused the deposition of colluvium on top of the $h$ and $i$ profiles; and (iv) the abandonment of the agricultural activity, probably at the arrival of the Spaniards, together with the fact that the canals have continued to drain the area, has caused the forest to grow over part of what was formerly a savannah. More studies involving phytoliths, C3 / C4 analyses along levee-backswamp catenas, and bone stable isotope analysis are needed in order to further our understanding of how pre-Columbians in the MMR sustained themselves, and in order to test the drainage hypothesis.

\section{Conclusions}

This paper presents the results of a study of soils carried out in the southeastern LM, in the Bolivian Amazon, and investigates possible links between the spatial distribution of pre-Columbian monumental mounds and soil properties. Our data show that important differences exist between soils forming on recent, mid- to late Holocene, sediments (PR1, where the highest density of monumental mounds is found) and soils forming on older sediments (PR0). The PR1 area in the MMR that is covered by sediments deposited by the palaeo-Grande River has better defined levees covered by dense forest, while older levees (PR0) are mostly covered by savannah vegetation dotted with $\mathrm{Na}+$ tolerant palms and bushes. Cation exchange capacity shows that backswamp soils in the PR0 area have toxic levels of exchangeable aluminium, while soils forming in the levees of PR0 show very high content of exchangeable sodium for agricultural soil (Fitzpatrick, 1986). Because of the high concentration of $\mathrm{Al}^{3+}$ and $\mathrm{Na}^{+}$, it is unlikely that agriculture could have sustained large sedentary populations here. This is consistent with the low density of monumental mounds found in the PR0 area. In contrast, soils formed in the backswamp of PR1 areas have no problems associated with aluminium toxicity because the relatively higher $\mathrm{pH}$ reduces Al's solubility and because they hold a far higher content of $\mathrm{Ca}^{2+}$. Soils forming on the PR1 levees have small concentrations of $\mathrm{Na}^{+}$, which do not represent a threat to agriculture. Here, on the more recent sediments of PR1, we find the highest density of monumental mounds. This study strengthens the hypotheses that (i) soil properties exerted an important control on pre-Columbian settlement patterns in the region, and (ii) the savannah-forest ecotone shifted as a result of the changes in drainage probably due to the preColumbian intervention. However, it is still not clear what 
kind of agriculturepre-Columbians practiced in the MMR, where no raised fields are found. Further research is needed in order to understand how pre-Columbians sustained themselves in this area and produced the surplus of food needed in order to finance the construction of the monumental earthworks that we find in today's MMR anthropogenic landscape.

Author contributions. U. Lombardo conceived and designed the study. S. Denier and H. Veit performed field work. S. Denier carried out laboratory analyses. H. Veit secured funding. U. Lombardo prepared the manuscript with contributions from all co-authors.

Acknowledgements. The present work has been funded by the Swiss National Science Foundation (SNSF) grant no. 200021122289 and 200020-141277/1 and performed under authorization no. 017/2012 issued by the Unidad de Arqueología y Museos (UDAM) del Estado Plurinacional de Bolivia. We thank M. R. Michel López from the Ministerio de Culturas and our Bolivian counterpart J. M. Capriles for their support. We thank the Sirionó people and Beni's Ganaderos for granting us free access to their land. Field work assistance by B. Vogt is gratefully acknowledged. Special thanks to E. Canal-Beeby for her good advice and improvement of the manuscript.

Edited by: J. Homburg

\section{References}

Abrol, I., Yadav, J. S. P., and Massoud, F.: Salt-affected soils and their management, FAO Soils Bulletin, FAO, Rome, 1988.

Arroyo-Kalin, M.: Slash-burn-and-churn: Landscape history and crop cultivation in pre-Columbian Amazonia, Quaternary Int., 249, 4-18, doi:10.1016/j.quaint.2011.08.004, 2012.

Balèe, W.: The culture of Amazonian Forests, in: Advances in Economic Botany, edited by: Posey, D. and Balèe, W., New York Botanical Garden, New York, 1-21, 1989.

Balée, W. and Erickson, C. L.: Time, complexity and historical ecology, in: Time and complexity in historical ecology: studies in the neotropical lowlands, edited by: Balée, W. and Erickson, C. L., Columbia University Press, New York, 1-17, 2006.

Barlow, J., Gardner, T. A., Lees, A. C., Parry, L., and Peres, C. A.: How pristine are tropical forests? An ecological perspective on the pre-Columbian human footprint in Amazonia and implications for contemporary conservation, Biol. Conserv., 151, 45-49, doi:10.1016/j.biocon.2011.10.013, 2012a.

Barlow, J., Parry, L., Gardner, T. A., Lees, A. C., and Peres, C. A.: Developing evidence-based arguments to assess the pristine nature of Amazonian forests, Biol. Conserv., 152, 293-294, doi:10.1016/j.biocon.2012.03.024, 2012b.

Boixadera, J., Poch, R. M., García-González, M. T., and Vizcayno, C: Hydromorphic and clay related processes in soils from the Llanos de Moxos (northern Bolivia), Catena, 54, 403-424, doi:10.1016/s0341-8162(03)00134-6, 2003.
Boone, R. D., Grigal, D. F., Sollins, P., Ahrens, R. J., and Armstrong, D. E.: Soil sampling, preparation, archiving, and quality control, in: Standard soil methods for long-term ecological research, edited by: Robertson, G. P., Coleman, D. C., Bledsoe, C. S., and Sollins, P., Oxford University Press, New York, 1999.

Bruno, M.: Carbonized Plant Remains from Loma Salvatierra, Department of Beni, Bolivia, Zeitschrift für Archäologie Außereuropäischer Kulturen, 3, 151-206, 2010.

Bush, M. B. and Silman, M. R.: Amazonian exploitation revisited: ecological asymmetry and the policy pendulum, Front. Ecol. Environ., 5, 457-465, doi:10.1890/070018, 2007.

Bush, M. B., Silman, M. R., de Toledo, M. B., Listopad, C., Gosling, W. D., Williams, C., de Oliveira, P. E., and Krisel, C.: Holocene fire and occupation in Amazonia: records from two lake districts, Philos. Trans. Roy. Soc., 362, 209-218, doi:10.1098/rstb.2006.1980, 2007.

Carabajal, C. C. and Harding, D. J.: SRTM C-Band and ICESat laser altimetry elevation comparisons as a function of tree cover and relief, Photogramm. Eng. Remote Sens., 72, 287-298, 2006.

Carneiro, R. L.: The history of ecological interpretations of Amazonia: does Roosevelt have it right?, in: Indigenous peoples and the future of Amazonia: an ecological anthropology of an endangered world, edited by: Sponsel, L., University of Arizona, Tucson, Arizona, 1995.

Cazanacli, D. and Smith, N. D.: A study of morphology and texture of natural levees - Cumberland Marshes, Saskatchewan, Canada, Geomorphology, 25, 43-55, doi:10.1016/S0169555X(98)00032-4, 1998.

Clement, C. R.: 1492 and the loss of amazonian crop genetic resources, I. The relation between domestication and human population decline, Econ. Bot., 53, 188-202, 1999.

Clement, C. R. and Junqueira, A. B.: Between a Pristine Myth and an Impoverished Future, Biotropica, 42, 534-536, doi:10.1111/j.1744-7429.2010.00674.x, 2010.

Cronan, C. S. and Grigal, D. F.: Use of Calcium/Aluminum Ratios as Indicators of Stress in Forest Ecosystems, J. Environ. Quality, 24, 209-226, doi:10.2134/jeq1995.00472425002400020002x, 1995.

Delhaize, E. and Ryan, P. R.: Aluminum Toxicity and Tolerance in Plants, Plant Physiol., 107, 315-321, 1995.

Denevan, W. M.: The Aboriginal Cultural Geography of the Llanos de Mojos of Bolivia, University of California Press, Berkeley, 1966.

Denevan, W. M.: A bluff model of riverine settlement in prehistoric Amazonia, Ann. Assoc. Am. Geogr., 86, 654-681, 1996.

Denevan, W. M.: Rewriting the late Pre-European history of Amazonia, J. Latin Am. Geogr., 11, 9-24, 2012.

Dickau, R., Bruno, M. C., Iriarte, J., Prümers, H., Jaimes Betancourt, C., Holst, I., and Mayle, F. E.: Diversity of cultivars and other plant resources used at habitation sites in the Llanos de Mojos, Beni, Bolivia: evidence from macrobotanical remains, starch grains, and phytoliths, J. Archaeol. Sci., 39, 357-370, doi:10.1016/j.jas.2011.09.021, 2012.

Erickson, C. L.: Lomas de ocupación en los Llanos de Moxos, in: Arqueologia de las tierras bajas, edited by: Coirolo, D., BraccoBoksar, A., and Bracco-Boksar, R., Comision Nacional de Arqueologia, Montevideo, Uruguay, 207-226, 2000.

Erickson, C. L.: The domesticated landscape of the Bolivian Amazon, in: Time and complexity in historical ecology: studies in the 
neotropical lowlands, edited by: Balée, W. and Erickson, C. L., Columbia University Press, New York, 236-278, 2006.

Erickson, C. L.: Amazonia: the historical ecology of a domesticated landscape, in: Handbook of South American archaeology, edited by: Silverman, H. and Isbell, W. H., Springer, Berlin, 157-183, 2008.

Fageria, N. K., Baligar, V. C., and Jones, C. A.: Growth and mineral nutrition of field crops, 3rd Edn., Taylor \& Francis US, 2011.

FAO: World reference base for soil resources 2006, Rome, 2006.

Fitzpatrick, E. A.: An introduction to soil science second edition, Longman group (FE), Hong Kong, 1986.

Fraser, J., Teixeira, W., Falcão, N., Woods, W., Lehmann, J., and Junqueira, A. B.: Anthropogenic soils in the Central Amazon: from categories to a continuum, Area, 43, 264-273, doi:10.1111/j.1475-4762.2011.00999.x, 2011.

García Miragaya, J., Schargell, R., Ramia, M., and Martín, L.: Chemical properties of soils where palm trees grow in Venezuela, Commun. Soil Sci. Plan., 21, 337-349, doi:10.1080/00103629009368236, 1990.

Hanagarth, W.: Acerca de la geoecología de las sabanas del Beni en el noreste de Bolivia, Instituto de ecología, La Paz, 1993.

Heckenberger, M. J. and Neves, E. G.: Amazonian Archaeology, Ann. Rev. Anthropol., 38, 251-266, doi:10.1146/annurevanthro-091908-164310, 2009.

Heckenberger, M. J., Petersen, J. B., and Neves, E. G.: Village size and permanence in Amazonia: two archaeological examples from Brazil, Latin Am. Antiquity, 10, 353-376, 1999.

Heckenberger, M. J., Christian Russell, J., Toney, J. R., and Schmidt, M. J.: The legacy of cultural landscapes in the Brazilian Amazon: implications for biodiversity, Philos. Trans. Roy. Soc., 362, 197-208, doi:10.1098/rstb.2006.1979, 2007.

Heckenberger, M. J., Russell, J. C., Fausto, C., Toney, J. R., Schmidt, M. J., Pereira, E., Franchetto, B., and Kuikuro, A.: Precolumbian urbanism, anthropogenic landscapes, and the future of the Amazon, Science, 321, 1214-1217, 2008.

Hijmanns, R. J., Cameron, S. E., Parra, J. L., Jones, P. G., and Jarvis, A.: Very high resolution interpolated climate surfaces for global land areas, Int. J. Climatol., 25, 1965-1978, doi:10.1002/joc.1276, 2005.

Jaimes-Betancourt, C.: La ceramica de la loma Salvatierra, Plural Editores, La Paz - Bolivia, 2012.

Johnson, A. W. and Earle, T.: The evolution of human societies, 2nd Edn., Standford University Press, Standford, California, 2000.

Junqueira, A. B. and Clement, C. R.: Reply to Barlow et al. (2011): Towards an integrated understanding of the pre-conquest human footprint in Amazonia, Biological Conservation, 152, 291-292, doi:10.1016/j.biocon.2012.03.025, 2012.

Kirch, P. V., Hartshorn, A. S., Chadwick, O. A., Vitousek, P. M., Sherrod, D. R., Coil, J., Holm, L., and Sharp,W. D.: Environment, agriculture, and settlement patterns in a marginal Polynesian landscape, Proc. Natl. Acad. Sci. USA, 101, 9936-9941, doi:10.1073/pnas.0403470101, 2004.

Langstroth Plotkin, R.: Biogeography of the Llanos de Moxos: natural and anthropogenic determinants, Geogr. Helv., 66, 183-192, doi:10.5194/gh-66-183-2011, 2011.

Lathrap, D. W.: The upper Amazon, Ancient peoples and places, 2, edited by: Daniel, G., Thames and Hudson, Southampton, 170$186,1970$.
Lehmann, J., Kern, D., Glaser, B., and Woods, W.: Amazonian dark earths: origin, properties, management, Kluwer Press, Dordrecht, 2003.

Levis, C., Souza, P. F. D., Schietti, J., Emilio, T., Pinto, J. L. P. D. V., Clement, C. R., and Costa, F.R. C.: Historical Human Footprint on Modern Tree Species Composition in the PurusMadeira Interfluve, Central Amazonia, PLoS ONE, 7, e48559, doi:10.1371/journal.pone.0048559, 2012.

Lombardo, U.: Raised Fields of Northwestern Bolivia: a GIS based analysis, Zeitschrift für Archäologie Außereuropäischer Kulturen, 3, 127-149, 2010.

Lombardo, U. and Prümers, H.: Pre-Columbian human occupation patterns in the eastern plains of the Llanos de Moxos, Bolivian Amazonia, J. Archaeological Sci., 37, 1875-1885, doi:10.1016/j.jas.2010.02.011, 2010.

Lombardo, U., Canal-Beeby, E., Fehr, S., and Veit, H.: Raised fields in the Bolivian Amazonia: a prehistoric green revolution or a flood risk mitigation strategy?, J. Archaeological Sci., 38, 502512, doi:10.1016/j.jas.2010.09.022, 2011a.

Lombardo, U., Canal-Beeby, E., and Veit, H.: Eco-archaeological regions in the Bolivian Amazon, Geogr. Helv., 66, 173-182, doi:10.5194/gh-66-173-2011, 2011 b.

Lombardo, U., May, J.-H., and Veit, H.: Mid- to late-Holocene fluvial activity behind pre-Columbian social complexity in the southwestern Amazon basin, The Holocene, 22, 1035-1045, doi:10.1177/0959683612437872, 2012.

Lombardo, U., Denier, S., May, J.-H., Rodrigues, L., and Veit, H.: Human-environment interactions in pre-Columbian Amazonia: The case of the Llanos de Moxos, Bolivia, Quaternary Int., 312, 109-119, doi:10.1016/j.quaint.2013.01.007, 2013a.

Lombardo, U., Szabo, K., Capriles, J. M., May, J.-H., Amelung, W., Hutterer, R., Lehndorff, E., Plotzki, A., and Veit, H.: Early and Middle Holocene Hunter-Gatherer Occupations in Western Amazonia: The Hidden Shell Middens, PLoS ONE, 8, e72746, doi:10.1371/journal.pone.0072746, 2013b.

Mayle, F. E., Langstroth, R. P., Fisher, R. A., and Meir, P.: Longterm forest-savannah dynamics in the Bolivian Amazon: implications for conservation, Phil. Trans. Roy. Soc., 362, 291-307, doi:10.1098/rstb.2006.1987, 2007.

McMichael, C. H., Piperno, D. R., Bush, M. B., Silman, M. R., Zimmerman, A. R., Raczka, M. F., and Lobato, L. C.: Sparse PreColumbian Human habitation in Western Amazonia, Science, 336, 1429-1431, doi:10.1126/science.1219982, 2012.

McMichael, C. H., Palace, M. W., Bush, M. B., Braswell, B., Hagen, S., Neves, E. G., Silman, M. R., Tamanaha, E. K., and Czarnecki, C.: Predicting pre-Columbian anthropogenic soils in Amazonia, Proc. Roy. Soc., 281, 20132475, doi:10.1098/rspb.2013.2475, 2014.

Meggers, B. J.: Environmental Limitation on the Development of Culture, American Anthropologist, 56, 801-824, 1954.

Meggers, B. J.: Amazonia: man and culture in a counterfeit paradise, Aldine-Atherton, Chicago, 1971.

Michel, M.: Desarrollo temprano de la agricultura de campos elevados en los llanos de Moxos, depto. de Beni, Bolivia, in: Formativo sudamericano, una revaluación. Ponencias presentadas en el Simposio internacional de arqueología sudamericana, Homenaje a Alberto Rex González y Betty J. Megger - Cuenca - Ecuador, edited by: Ledergerber-Crespo, P., Abya-Yala, Quito, 271-281, 1999. 
Moran, E.: Disaggregating Amazonia. A strategy for understanding biological and cultural diversity, in: Indigenous people and the Future of Amazonia, edited by: Sponsel, E. L., University of Arizona Press, Tucson, 71-95, 1995.

Navarro, G.: Clasificación de la vegetación de Bolivia, Centro de ecología difusión fundación Simón I. Patiño, Santa Cruz, Bolivia, 2011.

Peres, C. A., Gardner, T. A., Barlow, J., Zuanon, J., Michalski, F., Lees, A. C., Vieira, I. C. G., Moreira, F. M. S., and Feeley, K. J.: Biodiversity conservation in human-modified Amazonian forest landscapes, Biol. Conserv., 143, 2314-2327, doi:10.1016/j.biocon.2010.01.021, 2010.

Plotzki, A.: Late Pleistocene to Holocene fluvial dynamics and environmental conditions in the Llanos de Moxos, Bolivian Amazon, $\mathrm{PhD}$, Philosophisch naturwissenschaftlichen Fakultät, Universität Bern, Bern, 2013.

Prümers, H.: Der Wall führt zum See, Die Ausgrabungen 2005-2006 in der Loma Salvatierra (Bolivien), Zeitschrift für Archäologie Außereuropäischer Kulturen, 2, 371-379, 2008.

Prümers, H.: "Charlatanocracia" en Mojos? investigaciones arqueológicas en la Loma Salvatierra, Beni, Bolivia, Boletín de arqueología PUCP, 11, 103-116, 2009.

Prümers, H.: Die Untersuchungen der Jahre 2007-2008 zur vorspanischen Siedlungs geschichte in den Llanos de Mojos (Bolivien), Zeitschrift für Archäologie Außereuropäischer Kulturen, 3, 233-244, 2010.

Rebellato, L., Woods, W., and Neves, E. G.: Pre-Columbian settlement dynamics in the Central Amazon, in: Amazonian Dark Earths: Wim Sombroek's Vision, edited by: Woods, W., Teixeira, W. G., Lehmann, J., Steiner, C., and Rebellato, L., Springer, Dordrecht, Netherlands, 2009.

Roy, A., Sharma, A., and Talukder, G.: Some aspects of aluminum toxicity in plants, The Botanical Review, 54, 145-178, doi:10.1007/bf02858527, 1988.

Simpson, I., Adderley, W. P., Guðmundsson, G., Hallsdóttir, M., Sigurgeirsson, M., and Snæsdóttir, M.: Soil Limitations to Agrarian Land Production in Premodern Iceland, Hum. Ecol., 30, 423443, doi:10.1023/a:1021161006022, 2002.

Stahl, P. W.: Paradigms in paradise: revising standard Amazonian prehistory, The Review of Archaeology, 23, 39-51, 2002.
Urrego, D. H., Bush, M. B., Silman, M. R., Niccum, B. A., De La Rosa, P., McMichael, C. H., Hagen, S., and Palace, M.: Holocene fires, forest stability and human occupation in southwestern Amazonia, J. Biogeogr., 40, 521-533, doi:10.1111/jbi.12016, 2013.

Van Breemen, N. and Buurman, P.: Soil formation, 2nd Edn., Springer, Science + Businness Media, B.V., 2002.

Walker, J.: Agricultural Change in the Bolivian Amazon, Memoirs in Latin American Archaeology, University of Pittsburgh Latin American Archaeology Publications and Fundación Kenneth Lee, Trinidad, 2004.

Walker, J.: The Llanos de Mojos, in: Handbook of South American archaeology, edited by: Silverman, H. and Isbell, W. H., Springer, New York, 927-939, 2008.

Walker, J.: Ceramic assemblages and landscape in the mid-1st millennium Llanos de Mojos, Beni, Bolivia, J. Field Archaeol., 36 , 119-131, doi:10.1179/009346911x12991472411402, 2011 a.

Walker, J.: Social Implications from Agricultural Taskscapes in the Southwestern Amazon, Lat. Am. Antiq., 22, 275-296, 2011 b.

Whitney, B. S., Rushton, E. A., Carson, J. F., Iriarte, J., and Mayle, F. E.: An improved methodology for the recovery of Zea mays and other large crop pollen, with implications for environmental archaeology in the Neotropics, The Holocene, 22, 1087-1096, doi:10.1177/0959683612441842, 2012.

Whitney, B. S., Dickau, R., Mayle, F. E., Soto, J. D., and Iriarte, J.: Pre-Columbian landscape impact and agriculture in the Monumental Mound region of the Llanos de Moxos, lowland Bolivia, Quaternary Res., 80, 207-217, doi:10.1016/j.yqres.2013.06.005, 2013.

Zwally, H. J., Schutz, R., Bentley, C., Bufton, J., Herring, T., Minster, J., Spinhirne, J., and Thomas, R.: GLAS/ICESat L2 Antarctic and Greenland Ice Sheet Altimetry Data, Version 33. NASA DAAC at the National Snow and Ice Data Center, Boulder, Colorado USA, available at: http://nsidc.org/data/docs/daac/ glas_icesat_11_12_global_altimetry.gd.html (last access: 13 October 2014), 2012. 